\title{
Nutritional Significance and Antioxidant-Mediated Antiaging Effects of Finger Millet: Molecular Insights and Prospects
}

\author{
Anil Kumar ${ }^{1 * \dagger}$, Madhu Rani ${ }^{2 \dagger}$, Shalini Mani ${ }^{3 *}$, Pallavi Shah ${ }^{2}$, Dev Bukhsh Singh ${ }^{4}$, \\ Himabindu Kudapa ${ }^{5}$ and Rajeev K. Varshney ${ }^{5,6}$ \\ ${ }^{1}$ Rani Lakshmi Bai Central Agricultural University, Jhansi, India, ${ }^{2}$ Department of Molecular Biology and Genetic Engineering, \\ College of Basic Sciences and Humanities, G.B. Pant University of Agriculture and Technology, Pantnagar, India, \\ ${ }^{3}$ Department of Biotechnology, Centre for Emerging Diseases, Jaypee Institute of Information Technology, Noida, India, \\ ${ }^{4}$ Department of Biotechnology, Siddharth University, Kapilvastu, India, ${ }^{5}$ Centre of Excellence in Genomics \& Systems \\ Biology, International Crops Research Institute for the Semi-Arid Tropics, Patancheru, India, ${ }^{6}$ State Agricultural Biotechnology \\ Centre, Crop Research Innovation Centre, Murdoch University, Murdoch, WA, Australia
}

OPEN ACCESS

Edited by:

Enoch G. Achigan-Dako, Université d'Abomey-Calavi, Benin

Reviewed by:

Tahira Fatima,

Purdue University, United States

Nadia Fanou Fogny,

University of Abomey-Calavi, Benin

*Correspondence: Anil Kumar

anilkumar.mbge@gmail.com Shalini Mani

shalini.mani@jiit.ac.in

tThese authors have contributed equally to this work

Specialty section:

This article was submitted to

Crop Biology and Sustainability,

a section of the journa

Frontiers in Sustainable Food Systems

Received: 23 March 2021

Accepted: 27 August 2021

Published: 05 October 2021

Citation:

Kumar A, Rani M, Mani S, Shah P,

Singh DB, Kudapa $H$ and

Varshney RK (2021) Nutritional

Significance and Antioxidant-Mediated

Antiaging Effects of Finger Millet:

Molecular Insights and Prospects.

Front. Sustain. Food Syst. 5:684318.

doi: 10.3389/fsufs.2021.684318
Aging is a multifaceted process that is associated with progressive, lethal, and unalterable changes like damage to different molecules (DNA, proteins, and lipids), cells, tissues, and organs. It is an inevitable process but can be delayed by both genetic and dietary interventions. Besides aging, premature death and age-associated diseases can be dealt with diet regulation and the use of compounds that inhibit the stress responsiveness or promote the damage repair signaling pathways. Natural compounds offer a repertoire of highly diverse structural scaffolds that can offer hopeful candidate chemical entities with antiaging potential. One such source of natural compounds is millets, which are minor cereals with an abundance of high fiber, methionine, calcium, iron, polyphenols, and secondary metabolites, responsible for numerous potential health benefits. The present review article elucidates the nature and significance of different phytochemicals derived from millets with a major focus on finger millet and highlights all the important studies supporting their health benefits with special emphasis on the antiaging effect of these compounds. The present article also proposes the possible mechanisms through which millets can play a significant role in the suppression of aging processes and aging-related diseases by influencing genetic repair, protein glycation, and stress-responsive pathways. We further discuss well-established natural compounds for their use as antiaging drugs and recommend raising awareness for designing novel formulations/combinations from them so that their maximum antiaging potential can be harnessed for the benefit of mankind.

Keywords: aging, antioxidant, bioactive compounds, millets, natural products, phytochemicals

\section{INTRODUCTION}

In the past few decades, there is a tremendous growth in research work connoting that certain major component in diet influence aging and associated age-related diseases. These dietary components include a myriad of constituents like fiber for the glycemic index in diabetes, vegetables, and fruits for cardiovascular disease, certain fats (saturated, polyunsaturated, and trans fatty acids) for 
cardiovascular disease, and vitamin D and calcium for osteoporosis and bone fracture (Everitt et al., 2006) and many more. With increasing public awareness for the wellness of health considering nutrition as a major role-playing factor, phytochemicals such as polyphenols and dietary fiber have gained popularity for their innumerable health beneficial properties. Several crops like millets are known for their numerous health benefits attributed to their dietary fiber and polyphenol content (Taylor, 2017).

Aging is often a major risk factor associated with noncommunicable chronic diseases (NCDs) like cardiovascular disease, type II diabetes, certain cancers, obstructive pulmonary disease, osteoporosis, dementia, etc. (Shlisky et al., 2017). It is a complex multifaceted process, and many theories have been proposed to explain it. These theories include the free radical theory of aging which was later modified to the mitochondrial theory of aging by Harman (1972), the telomere shortening theory as proposed by Lu and Liu (2010), and the protein translational modification theory as proposed by Santos and Lindner (2017). Dietary components such as antioxidants and protein-modifying compounds influence different aspects as proposed in these theories and help delay and in cases overcome aging. Ribarič (2012) have described the epigenetic modifications by dietary factors which include direct effect on gene expression by influencing DNA methylation, histone modification, activation of nuclear receptors by ligands, and through modification of membrane receptor signaling cascades. Furthermore, the influence of caloric restriction on aging was reviewed in the above article with increasing clarity on molecular pathways like the mammalian target of rapamycin (mTOR), sirtuin pathway, and insulin/insulin-like growth factor signaling (IIS) cascades which are all involved in aging (Altintas et al., 2016; Chen et al., 2020; Yu et al., 2021). How these pathways are influenced by dietary components have helped us in establishing the major impact of dietary components on the aging process.

Millets are considered to have immense significance because of their nutritional and nutraceutical potential. Millets are an abundant source of minerals, dietary fibers, and phenolic compounds and offer health benefits such as antimicrobial, antidiabetic, anticancerous, antiartherosclerogenic effects, antioxidant, and antiaging properties (Yang et al., 2012; Si and Liu, 2014; Kumar et al., 2016). Among different types of millets, finger millet is known to possess almost the highest nutritional value (Taylor, 2017). In the recent past, various studies have also reported the preliminary antiaging effect of millet grains, mainly the finger millet (Hegde et al., 2002; Dykes and Rooney, 2006; Shobana et al., 2010; Zhang et al., 2011; Kakkar and Bais, 2014; Khan et al., 2015; Pei et al., 2016).

The present review covers the nutritional and phytochemical composition of finger millet and how they influence aging and age-related disorders. We further discuss wellestablished natural compounds for their use as antiaging drugs and recommend raising awareness for designing novel formulations/combinations from them so that their maximum antiaging potential can be harnessed for the benefit of mankind.

\section{MILLET: A WONDER GRAIN}

Millet includes the grains from the diverse group of forage grasses of the family Poaceae. They are considered "coarse cereals" similar to sorghum mostly due to their grain texture, which makes their processing as well as cooking inconvenient when compared with rice and wheat (Rao et al., 2017; Hassan et al., 2021). They are mainly grown in Asia and Africa and are in cultivation in East Asia for the last 10,000 years (Bhat et al., 2018). Millets produce small seed grains and are often cultivated as cereals. Millets are characterized by their remarkable abilities to survive in stress conditions, fairly resistant to pests and diseases, and are widely adaptable. Millet grains can be stored for a long duration during natural disasters such as famine (Obilana and Manyasa, 2002; Adekunle, 2012; Yang et al., 2012; Kumar et al., 2018).

India, several countries of Africa, and China produce the bulk of the world's millet crops. Several important millets grown in the Asian and African countries include barnyard millet (Echinochloa spp.), pearl millet (Pennisetum glaucum), foxtail millet (Setaria italica), finger millet (Eleusine coracana), little millet (Panicum sumatrense), kodo millet (Paspalum scrobiculatum), and proso millet (Panicum miliaceum) (Rao et al., 2017). Whereas, Tef (Eragrostic tef) and Fonio (Digitaria exilis) are grown in Ethiopia, Nigeria, Niger, Togo, Senegal, and Mali (Bhat et al., 2018). Most millets are grown in different regions of the world from east to west, which is evident from their colloquial names, foxtail millet as Italian millet, proso as French millet, barnyard as Japanese barnyard millet, indicating their growing region. Proso millet is cultivated in the USA as well as in Russia and is a popular bird feed in both countries, whereas foxtail millet is largely cultivated in China and India. Millets are predominantly used for food purposes in India as well as in other developing countries but are mainly used as feed ingredients in developed countries.

Pearl millet is the most commonly grown species with large grains and accounts for $40 \%$ of the world's total millet production (ICRISAT, 2007; Mariac et al., 2007). Except for sorghum and pearl millet, all other millets are known as small or minor millets (Obilana and Manyasa, 2002; ICRISAT, 2007; FAO, 2012) (Figure 1). Finger millet is mainly grown in Eastern and Southern African countries (Uganda, Kenya, the Democratic Republic of the Congo, Zimbabwe, Zambia, Sudan, Tanzania, Nigeria, and Mozambique) and Southern Asia (mainly India and Nepal).

\section{Nutritional Composition}

The nutritional content of food is an important aspect for the overall health and well-being of humans especially for better health and development to maximize the human genetic potential. Millets as food are a rich source of micronutrients and phytochemicals (Hassan et al., 2021). In comparison with main cereals like wheat, rice, sorghum, and maize, millets possess a high nutritional value (Parameswaran and Sadasivam, 1994). Being an abundant source of nutrients especially minerals, vitamins, dietary fiber, and phytochemicals, millets provide numerous health benefits. They are nutritionally important as they possess high calcium content $(0.38 \%)$, roughage or dietary fiber (18\%), and phenolic compounds (0.3-3\%) (Rao et al., 2017). 


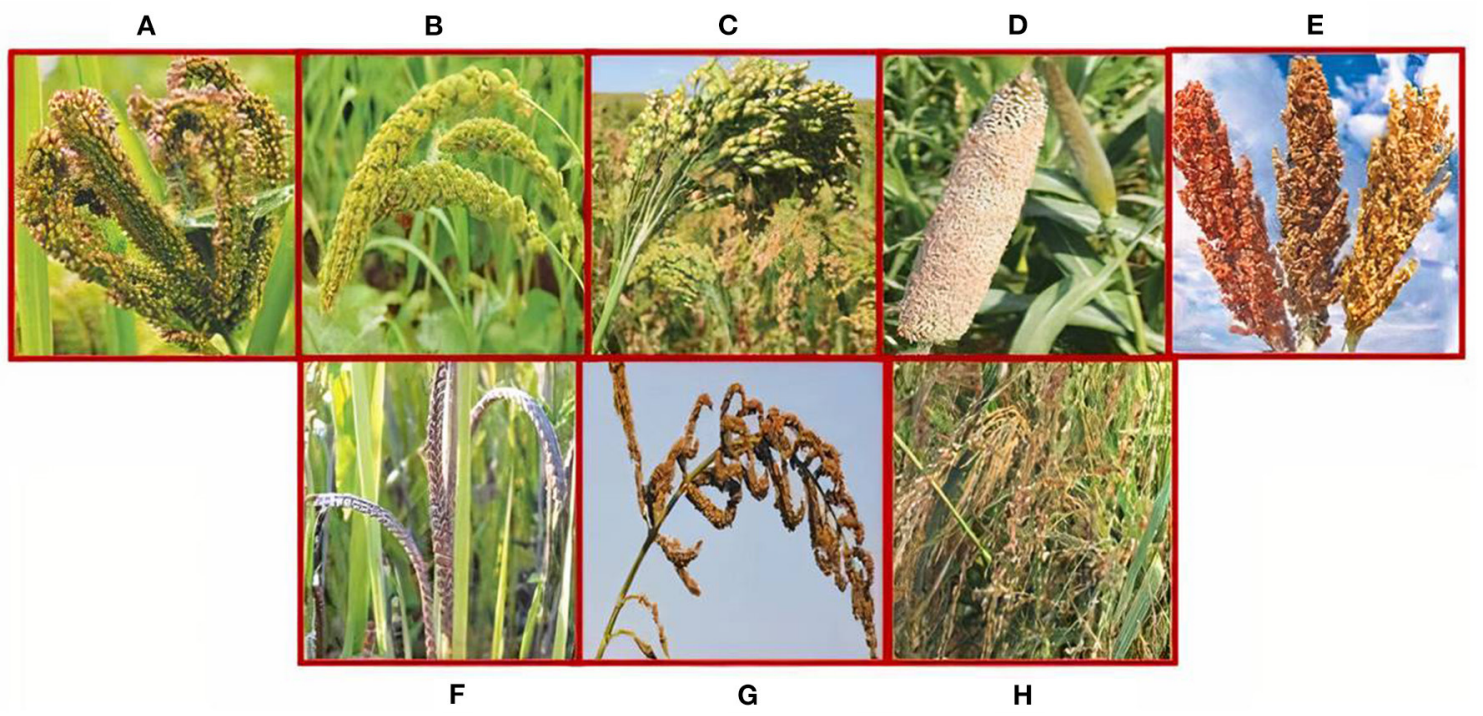

FIGURE 1 | Major millets: (A) finger millet (Eleusine coracana), (B) foxtail millet (Setaria italica), (C) proso millet (Panicum miliaceum), (D) pearl millet (Pennisetum glaucum), and (E) sorghum (Sorghum bicolor). Minor millets: (F) kodomillet (Paspalum scrobiculatum), (G) barnyard millet (Echinochola spp.), and (H) little millet (Panicum sumatrense).

Apart from these, proteins found in millet are rich in essential amino acids such as tryptophan, threonine, and sulfur-containing amino acids excluding lysine and threonine. They have a high-fat content in comparison with other cereals especially unsaturated fatty acids (Nithiyanantham et al., 2019). The abundance of phytochemicals and micronutrients of immense therapeutic potential signifies the importance of all varieties of millets (Mal et al., 2010; Singh et al., 2012). The average of the nutrient composition of different millets is shown in Table $\mathbf{1}$.

Millets possess proteins ranging from 7 to $12 \%$, carbohydrates in the range of $65-75 \%$, fat varying from 2 to $5 \%$, and dietary fiber in the range of $15-20 \%$. Of the different millet varieties, pearl millet is the richest in both protein (12-16\%) and lipids (4-6\%). Millet proteins contain greater amounts of healthy rich essential amino acids (Bhat et al., 2018; Shah et al., 2021). Finger millet, for example, contains a distinctive amount of sulfur-containing amino acids and is a better source of calcium and several micronutrients and pyridoxine. Furthermore, millets are rich in vitamin B complex. Due to the ample quantity of these key nutrients, millets or millet-based products are being used as food products (Subramanian and Viswanathan, 2007; Liu et al., 2012). On the other hand, millet proteins are poor in lysine similar to other cereals, and hence need to be complemented with lysine-enriched vegetables and animal proteins. The major portion of dietary fiber is made up of non-starch polysaccharides (95\%), and they are present in seed bran as well as endosperm. Traditionally prepared food items from millets have been a major part of the food consumed in Central America, Africa, and the Indian subcontinent. Most traditional products are flour based, and these include pancakes made from either fermented or unfermented dough, porridge or mudde, snacks, deep-fried products, sweet or sour local liquor, some non-alcoholic beverages, and decorticated grains, prepared similar to rice by boiling (Taylor, 2017; Bhat et al., 2018). Based on their nutritional components and henceforth nutraceutical aspect, different types of millets are consumed in different seasons of the year, conventionally. Almost all of these millets are a good source of both soluble and insoluble dietary fibers, which is contributed by both seed coat as well as endosperm cell walls, unlike in rice, wherein mostly the bran layers account for its dietary fiber content. Since the dietary fiber component of the food offers several physiological benefits including the health of the gastrointestinal tract, millets could be gainfully utilized in the preparation of functional and healthy foods for the target population. Along with nutrition, bioactive compounds found in millets are also recognized for their health beneficial effects, such as antioxidant, antidiabetic, antiaging properties, etc. (Sripriya et al., 1997; Kumari and Sumathi, 2002; Shobana et al., 2007; Banerjee et al., 2012; Shahidi and Chandrasekara, 2013; Kumar et al. 2016).

\section{Natural Compounds}

Phytochemicals obtained from millets are mostly secondary metabolites with molecular weights ranging from 150 to 30,000 Da in size. Phenolic acids, flavonoids, and tannins are the major polyphenols reported in different parts of the millet grain (Rao and Muralikrishna, 2002; Sreeramulu et al., 2009). Furthermore, it also consists of terpenes, betalians, organosulfides, indoles/glucosinolates/sulfur compounds, protein inhibitors, and other organic acids, along with dietary fiber and phytates. Most millets possess colored coats and some possess colored endosperm. Carotene constitutes the major coloring pigment and hence several millet varieties are known 
TABLE 1 | Proximate nutrient composition and nutritive value of various millets ( $\mathrm{g} / 100 \mathrm{~g} \mathrm{db}$ and $\mathrm{mg} / 100 \mathrm{~g} \mathrm{db})$.

\begin{tabular}{|c|c|c|c|c|c|c|c|c|c|c|c|c|}
\hline Variety & $\begin{array}{c}\text { Carbohydrate } \\
\text { (g) }\end{array}$ & $\begin{array}{l}\text { Protein } \\
\text { (g) }\end{array}$ & Fat (g) & Ash (g) & Fiber (g) & $\mathrm{Ca}(\mathrm{mg})$ & $\mathrm{Fe}(\mathrm{mg})$ & $\mathrm{Zn}(\mathrm{mg})$ & $\begin{array}{l}\text { Thiamin } \\
\text { (mg) }\end{array}$ & $\begin{array}{l}\text { Riboflavin } \\
\text { (mg) }\end{array}$ & $\begin{array}{l}\text { Niacin } \\
\text { (mg) }\end{array}$ & $\begin{array}{c}\text { Energy } \\
\text { (kcal) }\end{array}$ \\
\hline Sorghum & 71 & 10.4 & 3.1 & 1.8 & 2.0 & 25 & 5.4 & 3.1 & 0.38 & 0.15 & 4.3 & 329 \\
\hline Finger millet & 59-75 & $6.9-10.9$ & 1.5 & 2.6 & 15.2 & 350 & 3.9 & 3.13 & 0.42 & 0.19 & 1.1 & 336 \\
\hline Kodo millet & $72-76$ & $6.2-13.1$ & $3.2-4.9$ & 3.3 & 5.2 & 35 & 1.7 & $1.9-2.4$ & 0.15 & 0.09 & 2.0 & 353 \\
\hline Foxtail millet & 55-69 & 11.2 & 4.0 & 3.3 & 9.4 & 31 & 2.8 & 2.92 & 0.59 & 0.11 & 3.2 & 351 \\
\hline Fonio millet & $68-75$ & 8.4 & 3.3 & 3.4 & 18.2 & 20 & 2.1 & 1.5 & 0.17 & 0.22 & 1.15 & 379 \\
\hline Little millet & 76 & 15 & 4.5 & 5.4 & 2.5 & 17 & 9.3 & 5.25 & 0.30 & 0.09 & 3.2 & 329 \\
\hline Barnyard millet & 74 & 11.0 & 5.2 & 4.5 & 13.6 & 22 & 18.6 & 3 & 0.33 & 0.10 & 4.2 & 300 \\
\hline Pearl millet & $67-72$ & 11.8 & 5.1 & 2.2 & 13.8 & 42 & 11.0 & 3.29 & 0.38 & 0.21 & 2.8 & 363 \\
\hline Proso millet & $64-76$ & 12.6 & $2.9-11.6$ & 2.7 & 13.1 & 15 & 2.2 & 2.36 & 0.41 & 0.28 & 4.54 & 316 \\
\hline
\end{tabular}

All values represent mean/range of reliable published data.

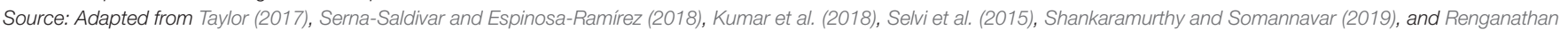
et al. (2020).

to have beta-carotene. Rich polyphenol content is responsible for the antioxidant potential of millets. The gelatinization temperature of the millet starch is slightly higher compared with rice and wheat. It also differs from other cereal starches concerning the crystallinity and the amylose and amylopectin organization. Hence, millet-based diet/foods may digest slowly compared with other cereal foods.

\section{Polyphenols}

Polyphenols are naturally occurring secondary metabolites which are generally characterized by the presence of multiple phenol rings (Pandey and Rizvi, 2009; Manuja et al., 2013). Several polyphenols have been detected from different plant species, and a majority of them are derivatives of phenylalanine or another precursor shikimic acid. Polyphenols are categorized on the basis of the number of phenol rings and how these rings are bound to each other. The major classes consist of phenolic acids (derivatives of benzoic acid and cinnamic acid), flavonoids, lignans, and stilbenes (Supplementary Figures S1, S2). Polyphenols are abundant in millets and are one of the most marketed dietary supplements (Ferguson, 2001). The finger millet seed coat is abundant in polyphenols when compared with many other kinds of cereal such as wheat, rice, barley, and maize (Viswanath et al., 2009).

\section{Phenolic Compounds}

Grain phenolics can exist both as free, soluble forms as well as insoluble bound forms. The majority of the phenolics found in millet exist as glycosides, whereas ferulic acid is the major bound phenolic acid (18.60 mg/100 g) and protocatechuic acid is the major free phenolic acid (45.0 mg/100 g) (Rao and Muralikrishna, 2002). The seed coat of finger millet is known to be rich in many potent antioxidant phenolics mostly benzoic acid derivatives (85\%) such as gallic acid, protocatechuic acid, $p$-hydroxybenzoic acid, vanillic acid, and syringic acid (Hegde et al., 2002; Rao and Muralikrishna, 2003; Chandrasekara and Shahidi, 2010), whereas the rest consists of either flavonoid like quercetin or cinnamic acid derivatives such as trans-cinnamic acid, p-coumaric acid, caffeic acid, and sinapic acid followed by condensed tannins
(Chethan and Malleshi, 2007; Shah et al., 2021). Apart from these bound phenolic acids such as ferulic and $p$-coumaric acid are also found in abundance in finger millet (Table 2).

Apart from these phenolics, direct infusion electrospray ionization mass spectrometry (ESI MS) of the extract from seed coat elucidated the presence of luteolin, naringenin, kaempferol, phloroglucinol, apigenin, catechins, malic acid, epigallocatechins, diadzein, and catechingallates (Shobana et al., 2009). Among various millets studied, finger millet had the highest content of $\leq 300 \mu \mathrm{mol}$ catechin equivalents/g of the defatted meal followed by foxtail, little, pearl, and proso millets. Furthermore, finger millet is the richest in condensed tannins (Dykes and Rooney, 2006). A recent report showed that finger millet varieties with darker color from Northern Malawi had higher polyphenols and antioxidant properties in comparison with the lighter ones. It means that the dark-colored finger millet varieties have greater potential for use as functional food ingredients as they possess higher amounts of natural antioxidants than lightcolored varieties (Xiang et al., 2019).

\section{Micronutrients}

As the name suggests, micronutrients are required in very few quantities for human health. However, micronutrient deficiency and their imbalance cause various age-related diseases in humans like obesity, diabetes, osteoporosis, etc. The minerals and vitamins are called micronutrients. Worldwide, more than 2 billion people are suffering from one or other age-related chronic micronutrient deficiencies (MNDs) whereas more than 800 million people are undernourished (Kumssa et al., 2015; Beal et al., 2017). In millets, the mineral content range is from 1.7 to $4.3 \mathrm{~g} / 100 \mathrm{~g}$ which is a comparatively higher side than that of main cereals such as wheat $(1.5 \%)$ and rice $(0.6 \%)$. Minerals play a chief role in structure and rigidity, muscular contractions, formation of strong bones and teeth, oocyte activation, blood clotting, oxygen transport, regulation of heartbeat, maintenance of fluid balance, nerve signal transmission, etc. (Kulkarni et al., 2018; Kumar et al., 2018). Calcium and iron deficiencies are mainly observed in developing countries. A large number of people are suffering from osteoporosis in India. The calcium 
TABLE 2 | Active ingredients of finger millet and their mechanism of action for enhancing the lifespan.

\begin{tabular}{llll}
\hline $\begin{array}{l}\text { Active } \\
\text { ingredients/bioactive }\end{array}$ & $\begin{array}{l}\text { Experimental } \\
\text { model }\end{array}$ & Efficacy & Mechanism \\
peptides & &
\end{tabular}

Dietary fiber, phytate, and total phenolics of seed coat matter of finger millet

Diadzene, gallic, coumaric, synringic, and vanillic acids of finger millet

Seed coat matter of black finger millet

Formulated finger millet

Ferulic and cinnamic acids of kodo millet

Whole grain and bran of finger millet

Polyphenol of finger millet

Ethanolic extract from finger Italian millet

Carotenoids and vitamin E of finger millet

Methanolic extract of finger millet

Whole grain extracts of finger millet (Oshadha and Rawana), proso millet, white finger millet, kodo millet, foxtail millet

Free and bound phenolics from finger millet varieties

Proanthocyanidins of finger millet

\section{Benzoic acids}

Protocatechuic acid (PCA) of finger millet seed coat

Gallic acid of finger millet seed coat
Streptozotocininduced diabetes model rat

$\begin{array}{ll}- & \text { Antioxidant activity } \\ \text { Streptozotocin- } & \begin{array}{l}\text { Antioxidative and } \\ \text { induced diabetes }\end{array} \\ \text { model rat } & \text { antiabetic activity }\end{array}$

Alloxan-induced diabetes mellitus model male Wistar albino rats

$-$

High-fat-diet-fed LACA model mice

$\begin{array}{ll}- & \text { Antioxidant activity } \\ - & \text { Antidiabetic and antioxidant } \\ & \text { activity } \\ - & \text { Antioxidant activity } \\ - & \text { Protective role against } \\ - & \text { diabetes mellitus } \\ - & \text { Antidiabetic, antialpha } \\ & \text { amylase and } \\ & \text { antiglucosidase activity }\end{array}$

- Antioxidant activity

Antioxidant activity

Antibacterial, antiviral, neurological effect, antiatherosclerotic, antifibrotic, antiaging, antiulcer, anticancer

Antioxidant, anticarcinogenic, antimicrobial, anti-inflammatory, antimelanogenic, neuroprotective, hepatoprotective
Reduced urinary glucose excretion, regulation of postprandial glycemia reduced the lipid levels and atherogenic index, reduce levels of blood and urinary creatinine and attenuated nephromegaly, anticataractogenic property, lower the levels of AGE, HbA1c, AR activity, and lesser lenticular opacity

Inhibition of oxidation of linoleic acid and reduction of ferrous to ferric iron

Reduced the serum levels of alanine transaminase (ALT), aspartate transaminase (AST), and alkaline phosphatase (ALP) and elevation in catalase (CAT) and superoxide dismutase (SOD) and lowered the thiobarbituric acid reactive substances (TBARS)

Lower the glucose level, cholesterol, triglycerides, and low-density lipoproteins (LDL)

Free radical scavenging activity

Prevention of obesity by regulation of obesity-related genes, improved lipid profile and anti-inflammatory status, suppresses oxidative stress

Inhibits superoxide, hydroxyl, and nitric oxide radicals

Inhibits glycation

Free radical scavenging activity

Inhibits glycosylation of collagen

Inhibition of early glycation, middle glycation and reversal of antiglycated products

Free radical scavenging activity

Free radical scavenging activity

Antiaging ability is induced as it increases the activity of glutathione peroxidase and catalase and decreases the malondialdehyde level.

Induces antiaging effect due to its ROS quenching and antiglycation activity
Viswanath et al. (2009)

Shobana et al., 2010

Okoyomoh et al., 2013

Nadro and

Elkanah, 2017

Sharma S. et al. (2017)

Murtaza et al., 2014

Bindu and Malleshi, 2003

Ofosu et al., 2020

Chethan et al. 2008

Hegde et al., 2002

Senevirathne et al., 2021

Xiang et al., 2019

Dykes and Rooney, 2006

Zhang et al., 2011; Kakkar and Bais, 2014; Khan et al., 2015

Panich et al., 2012; Badhani et al., 2015 
TABLE 2 | Continued

\begin{tabular}{|c|c|c|c|c|}
\hline $\begin{array}{l}\text { Active } \\
\text { ingredients/bioactive } \\
\text { peptides }\end{array}$ & $\begin{array}{l}\text { Experimental } \\
\text { model }\end{array}$ & Efficacy & Mechanism & References \\
\hline $\begin{array}{l}\text { Syringic acid of finger millet } \\
\text { seed coat }\end{array}$ & - & Antimitogenic, antidiabetic & $\begin{array}{l}\text { Eradicates free radicals due to their } \\
\text { antioxidant potential }\end{array}$ & $\begin{array}{l}\text { Wei et al., 2012; } \\
\text { Muthukumaran } \\
\text { et al., } 2013\end{array}$ \\
\hline $\begin{array}{l}\text { Vanillic acid and its } \\
\text { derivatives of finger millet } \\
\text { seed coat }\end{array}$ & - & $\begin{array}{l}\text { Antimicrobial, antiaging, } \\
\text { hepatoprotective, antivenom }\end{array}$ & $\begin{array}{l}\text { Inhibits collagenase and elastase } \\
\text { activity }\end{array}$ & $\begin{array}{l}\text { Dhananjaya et al., } \\
\text { 2009; Itoh et al., } \\
\text { 2009; Widowati } \\
\text { et al., } 2016\end{array}$ \\
\hline \multicolumn{5}{|l|}{ Cinnamic acid derivatives } \\
\hline $\begin{array}{l}p \text {-Coumaric acid of finger } \\
\text { millet seed coat }\end{array}$ & - & $\begin{array}{l}\text { Antioxidant,anti- } \\
\text { inflammatory, } \\
\text { antimutagenic, antiulcer, } \\
\text { antiplatelet, and anticancer }\end{array}$ & Due to its potent antioxidant potential & $\begin{array}{l}\text { Pragasam et al., } \\
2013 \text {; Pei et al., } \\
2016\end{array}$ \\
\hline $\begin{array}{l}\text { Ferulic acid of finger millet } \\
\text { seed coat }\end{array}$ & - & $\begin{array}{l}\text { Antioxidant, antimicrobial, } \\
\text { anti-inflammatory, } \\
\text { antithrombosis, and } \\
\text { anticancer activities }\end{array}$ & $\begin{array}{l}\text { Inhibits the expression of some } \\
\text { cytotoxic enzymes, such as nitric } \\
\text { oxide synthase, caspase, and } \\
\text { cyclooxygenase- } 2\end{array}$ & $\begin{array}{l}\text { Rao and } \\
\text { Muralikrishna, } \\
\text { 2002; Ou and } \\
\text { Kwok, 2004; Pei } \\
\text { et al., } 2015\end{array}$ \\
\hline $\begin{array}{l}\text { Caffeic acid of finger millet } \\
\text { seed coat }\end{array}$ & - & $\begin{array}{l}\text { Antioxidant, anti-ischemia } \\
\text { reperfusion, antithrombosis, } \\
\text { antihypertension, } \\
\text { antifibrosis, antivirus, and } \\
\text { antitumor }\end{array}$ & Potent antioxidant potential & Jiang et al., 2005 \\
\hline $\begin{array}{l}\text { Sinapic acid of finger millet } \\
\text { seed coat }\end{array}$ & - & $\begin{array}{l}\text { Antioxidant, antimicrobial, } \\
\text { anti-inflammatory, } \\
\text { anticancer and antianxiety } \\
\text { activities }\end{array}$ & $\begin{array}{l}\text { Elastase, tyrosinase and collagenase } \\
\text { inhibitory activities }\end{array}$ & $\begin{array}{l}\text { Chen, 2016; } \\
\text { Taofiq et al., } 2017\end{array}$ \\
\hline \multicolumn{5}{|l|}{ Flavonoids } \\
\hline $\begin{array}{l}\text { Quercetin of finger millet } \\
\text { seed coat }\end{array}$ & - & $\begin{array}{l}\text { Antioxidant, antiaging, } \\
\text { antiobesity, } \\
\text { anticarcinogenic, antiviral, } \\
\text { antibacterial, and } \\
\text { anti-inflammatory effects }\end{array}$ & $\begin{array}{l}\text { Proteasome activator with antioxidant } \\
\text { properties that consequently } \\
\text { influence cellular lifespan }\end{array}$ & $\begin{array}{l}\text { Chethan et al., } \\
\text { 2008; } \\
\text { Chondrogianni } \\
\text { et al., 2010; Wang } \\
\text { et al., } 2016\end{array}$ \\
\hline $\begin{array}{l}\text { Catechin and its derivatives } \\
\text { of finger millet seed coat } \\
\text { (gallocatechin, epicatechin, } \\
\text { and epigallocatechin) }\end{array}$ & - & $\begin{array}{l}\text { Antioxidant, } \\
\text { anti-inflammatory, } \\
\text { antimutagenic effects, } \\
\text { antiaging, as well as } \\
\text { cardiovascular } \\
\text { disease-preventive } \\
\text { properties. }\end{array}$ & $\begin{array}{l}\text { Eradicates free radicals, stimulates } \\
\text { the activity of the regulatory protein } \\
\text { SIRT1 }\end{array}$ & $\begin{array}{l}\text { Sripriya et al., } \\
\text { 1996; Unno et al., } \\
\text { 2011; Hong et al., } \\
2013\end{array}$ \\
\hline
\end{tabular}

content of finger millet (ca. $340 \mathrm{mg} / 100 \mathrm{~g}$ ) is almost eight times higher than major cereals wheat and rice. Therefore, finger millet is the richest source of calcium to overcome age-related diseases like osteoporosis (Puranik et al., 2017; Sharma D. et al., 2017). The consumption of pearl millet and barnyard millet help in protection from anemia because they have been found as the richest source of iron. The highest content of zinc (4.1 $\mathrm{mg} / 100 \mathrm{~g}$ ) in foxtail millet as compared with other millets and stable cereals make it special to combat zinc-associated diseases. Foxtail millet is also a good source of iron $(2.7 \mathrm{mg} / 100 \mathrm{~g})$. The immune system is boosted by the intake of zinc and iron (Kulkarni et al., 2018; Kumar et al., 2018). Millets are also the ultimate source of $\beta$-carotene and $\mathrm{B}$ vitamins like riboflavin, niacin, and folic acid as compared with wheat and rice. The foxtail millet has the richest source of thiamine $(0.60 \mathrm{mg} / 100 \mathrm{~g})$ whereas the barnyard millet has the highest content of riboflavin $(4.20 \mathrm{mg} / 100 \mathrm{~g})$ (Table 1). The regular consumption of millets in our diets aids to curb nutritional deficiencies and age-related diseases (Chandel et al., 2017). The presence of antinutrients in millets like phytates, polyphenols, and tannins is responsible for the reduction in mineral bioavailability by chelating multivalent cations such as $\mathrm{Ca}, \mathrm{Zn}, \mathrm{Fe}, \mathrm{Mg}$, and $\mathrm{K}$. Besides this, the rich content of protease and amylase inhibitors in millets also causes reduced digestibility of millet grains. Therefore, food processing techniques are used to enhance nutritional content, increase digestibility, and bioavailability of nutrients with a reduction in antinutrients and increase the accumulation of nutrients in milled grains (Sharma D. et al., 2017; Vinoth and Ravindhran, 2017). The applications of genetic engineering and genome-editing tools are also useful in facilitating nutrient 


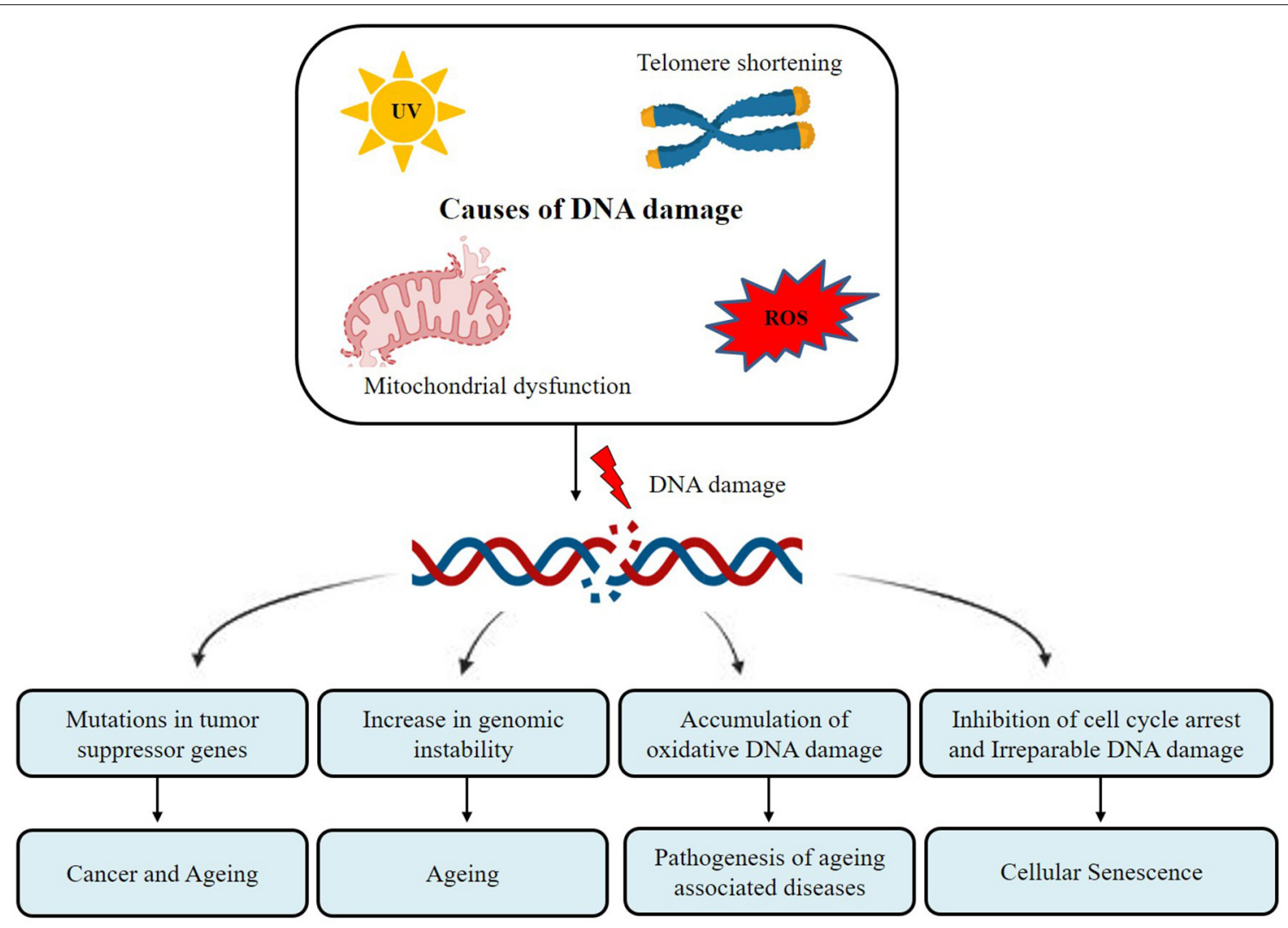

FIGURE 2 | Different types of DNA damage result in aging and associated diseases.

accumulation in grains and the prevention of the synthesis of antinutrients.

\section{HEALTH BENEFITS OF MILLET CONSUMPTION}

Millets are better alternatives to common cereal grains due to their nutraceutical properties and immense health-promoting attributes. Millets contain ample amounts of fiber and lesser amounts of simple sugars responsible for their relatively low glycemic index. Millets have been shown to aid low blood sugar levels in comparison with wheat or rice (Kumari and Sumathi, 2002) and thus possess antidiabetic properties. Millets similar to whole grains are abundant in magnesium, which acts as a cofactor for enzymes especially involved in the glucose uptake and secretion of insulin. Magnesium has been reported to reduce the effects of migraines and heart attacks. Niacin in millets is hypocholesteremic in nature. Consumption of millets also reduces the $\mathrm{C}$-reactive protein and unhealthy lipids and thus may prevent cardiovascular diseases. Millets provide plenty of phosphorus which plays an important role in cell structure determination. Aside from constituting the bone mineral matrix, phosphorus is an essential component of adenosine triphosphate (ATP), the energy currency of the cell. Apart from the abovementioned health benefits, the compounds of millets are also known to possess antioxidant and antiaging properties. Previous reports have well-established the antioxidant potential of many millet varieties (Chandrasekara and Shahidi, 2010). Regulation of oxidative stress, through antioxidant administrations, is also capable of controlling different healthrelated issues such as diabetes, cancer, neurodegenerative disorders, cardiovascular problems, and age-associated diseases. Thus, in the benefit of the current review, the different properties of millets are explained in relation to aging.

\section{BIOACTIVE COMPOUNDS: ANTIAGING AND ANTIOXIDANT PROPERTIES}

Antioxidants derived from plants, such as phenolics and flavonoids have numerous biological effects. Antioxidants play a major role in the reduction of lipid peroxidation, a process that plays a key role in cancer and aging (Namikii, 1990). Antioxidants provide stable radical intermediates which prevent the oxidationinduced damage of fatty acids and oils (Lobo et al., 2010). Polyphenols like phenolic acids, flavonoids, and tannins found in the seed coat of millet seeds act as reducing agents such as free radical quenchers, metal chelators, and singlet oxygen quenchers (Banerjee et al., 2012). Potent antioxidant attributes of polyphenols arise as a result of their ability to act as hydrogen 


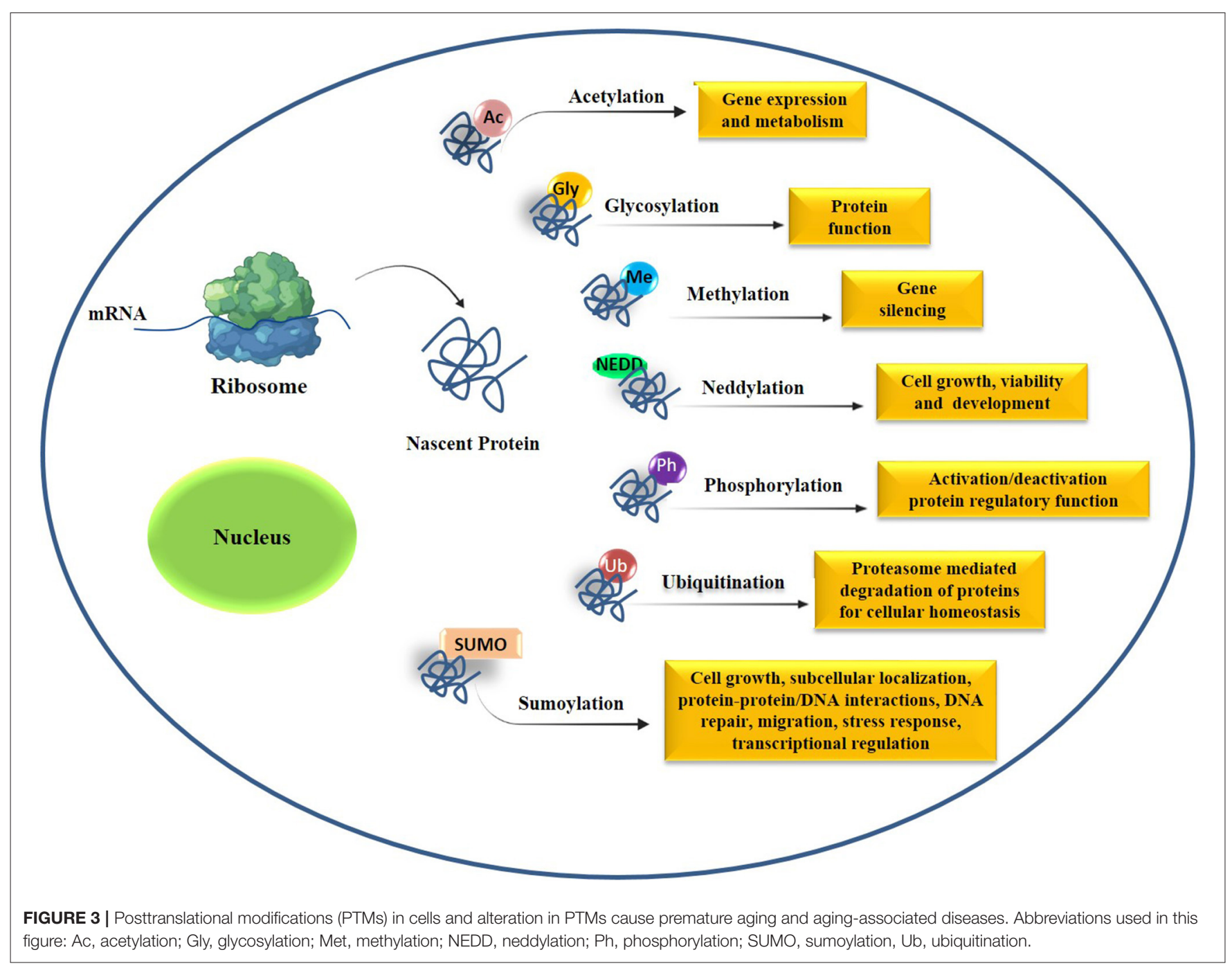

atom donors via hydroxyl groups on phenol rings to electrondeficient free radicals.

Polyphenols overcome oxidative stress by the maintenance of balance between oxidants and antioxidants. Being antioxidant, these compounds may show different health benefits and primarily may act as antiaging compounds as well. Polyphenols presently have gained the status of "life span essentials" as they play a crucial role in maintaining health (Chandrasekara and Shahidi, 2010). Millet grain is entirely edible, and conventional food recipes are prepared from wholemeals throughout Asian and African countries. This indicates that the phytochemicals of millets such as polyphenols are consumable without any adverse effects on human health. The content and composition of these polyphenols vary depending on the type of millet grain and have received considerable interest because of their antioxidant, antiaging, and other nutraceutical properties (Chandrasekara and Shahidi, 2011). Additionally, some of the other health benefits such as hypoglycemic (Kumari and Sumathi, 2002), hypocholesterolemic (Hegde et al., 2002) and antiulcerative
(Tovey, 1994) properties can further be contributed to a large extent to their polyphenol content.

Different types of millets are known to be rich in different polyphenols which may act as potent antioxidants which are critical for exhibiting antiaging properties. For example; different types of millet grains contain dimers and trimers of ferulates which possess comparatively higher antioxidant activity (Chandrasekara and Shahidi, 2011). Very recent findings on phenolics of millet grain varieties that are cultivated in South Korea like millet (M), Italian millet (IM), barnyard millet (BM), and finger Italian millet (FIM) have shown their potent antioxidant potential and antiglycation properties effective against diabetes mellitus which is a main age-related disorder. It has also been reported that the finger Italian millet has the highest total phenolics and total flavonoid content as compared with barnyard millet and Italian millet. Therefore, finger Italian millet is a crucial nutraceutical as it possesses high antioxidant and antidiabetic activity (Ofosu et al., 2020). Colored (brown, reddish, or red) finger millet varieties from the Northern Malawi region exhibit more significant antioxidant activity than 


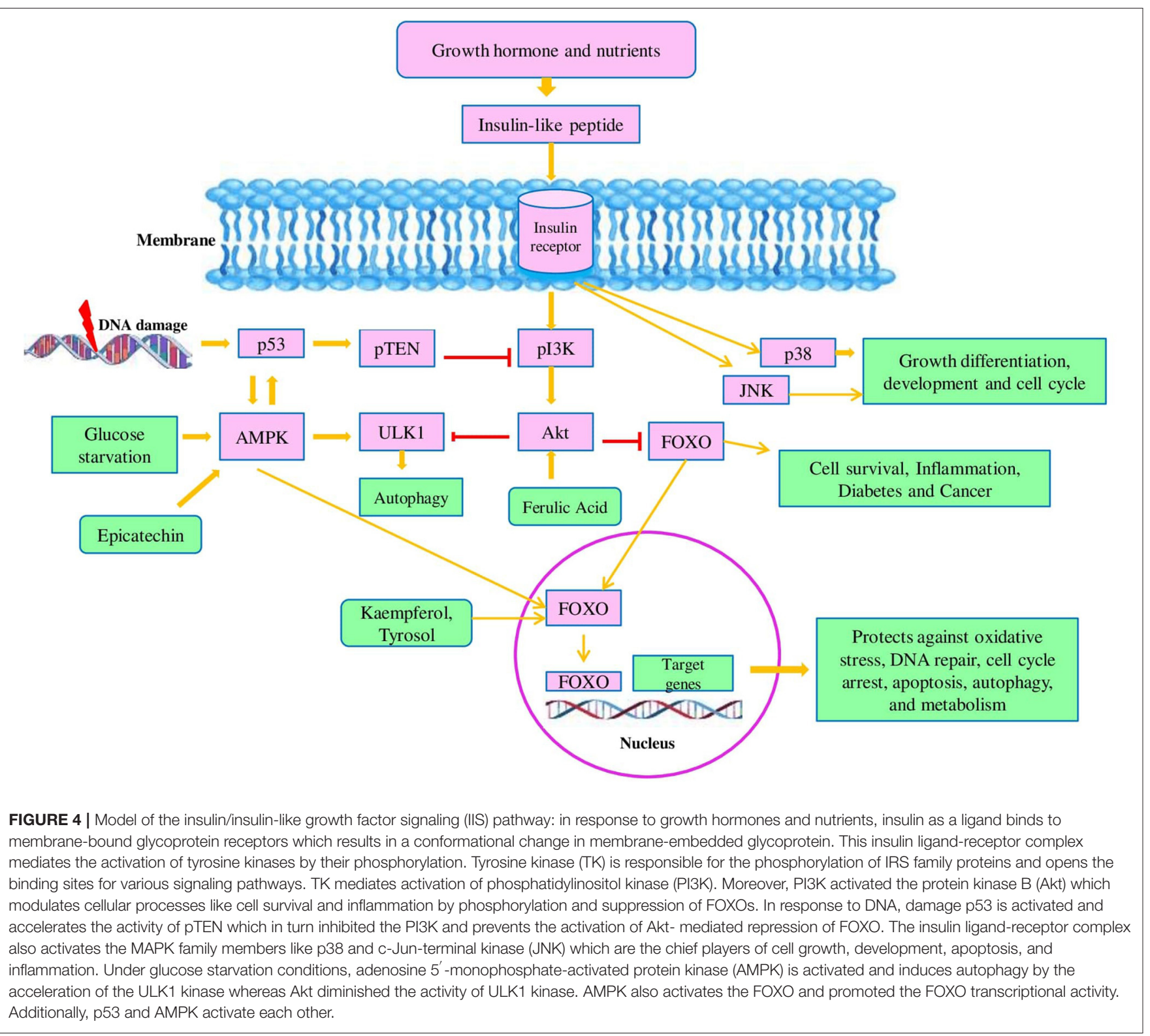

the white variety due to the presence of high amounts of phenolic compounds, tannins, and flavonoids in them (Xiang et al., 2019). Amadou et al. (2011) have studied the antioxidant efficiency of defatted foxtail millet (DFMB) and observed that it can scavenge free radicals and superoxide anions.

Watanabe (1999) isolated two flavones viz., luteolin and tricin, with antioxidant activity from Japanese barnyard millet. Luteolin along with its glycosides possesses health-beneficial properties such as antioxidant, anti-inflammatory, cancer preventive, and antiarrhythmic activities (Lin et al., 2008). Tricin is also known for its antitumor and antimetastatic properties (Yue et al., 2020). Finger millet showed the highest total flavonoid content in defatted meals followed by kodo and foxtail millets. Studies were carried out on the natural antioxidants in edible flours of small millets. Ferulic acid exhibits very strong antioxidant, free radical scavenging, and anti-inflammatory activity (Shahidi et al., 1992; Castelluccio et al., 1995).

Free radical production in excess and lipid peroxidation are the major reasons for chronic diseases such as diabetes, cardiovascular disease, cancer, cataract, and aging. Nonenzymatic glycosylation whereby chemical reaction occurs in between the aldehyde group of reducing sugar and the amino group of proteins plays a major role in the complications of diabetes and aging (Rowan et al., 2018). Non-enzymatic glycosylation and cross-linking of collagen are induced by free radicals, whereas free radical scavengers such as polyphenols inhibit these reactions ( $\mathrm{Fu}$ et al., 1992). Polyphenols act as antioxidant compounds that suppress excessive oxidation responsible for cancer and aging (Namikii, 1990). Thus, any compound which can neutralize these free radicals can in 


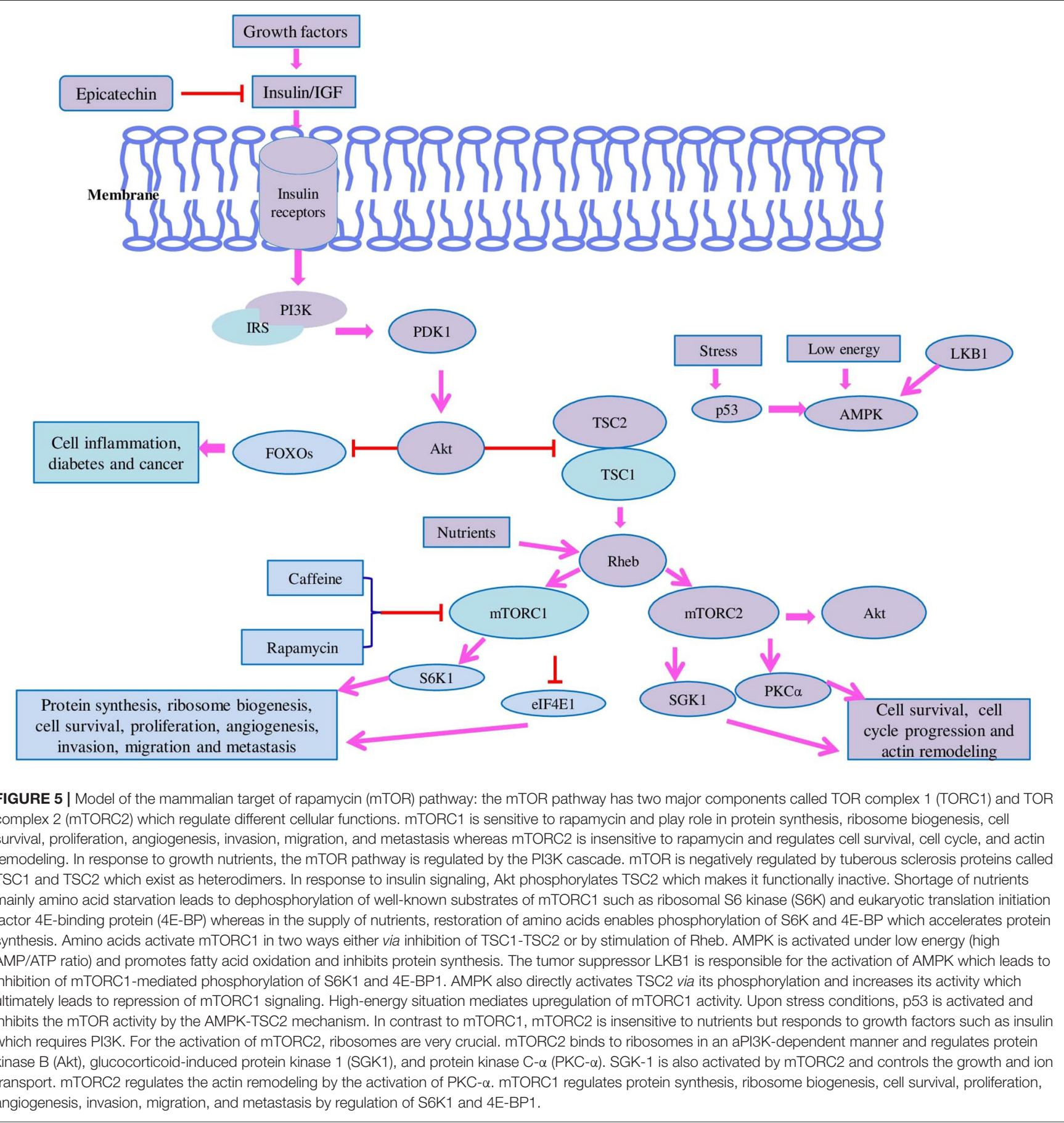

turn exhibit antiaging effect. Senevirathne et al. (2021) have very recently observed antidiabetic properties from different varieties of millets such as finger millet, proso millet, white finger millet, kodo millet, and foxtail millet cultivated in Sri Lanka. The inhibition of early glycation, middle glycation, and reversal of antiglycated products by these millets in diabetes make them crucial functional food for delaying the aging process. These millet varieties also showed anti- $\alpha$-amylase activity, and suppression of this enzyme is required for better carbohydrate digestion and maintains the blood glucose levels for diabetic patients (Table 2).

Hegde et al. (2005) studied the effects of the antioxidant properties of millets on oxidative stress and glycemic status in alloxan-induced rats. The alloxan-induced rats when fed with a diet enriched with finger millet showed a significant decrease in blood glucose and cholesterol level. Tail tendon collagen glycation was reduced in the finger millet-fed rats. Diabetic groups fed on finger millet diet showed alleviated 


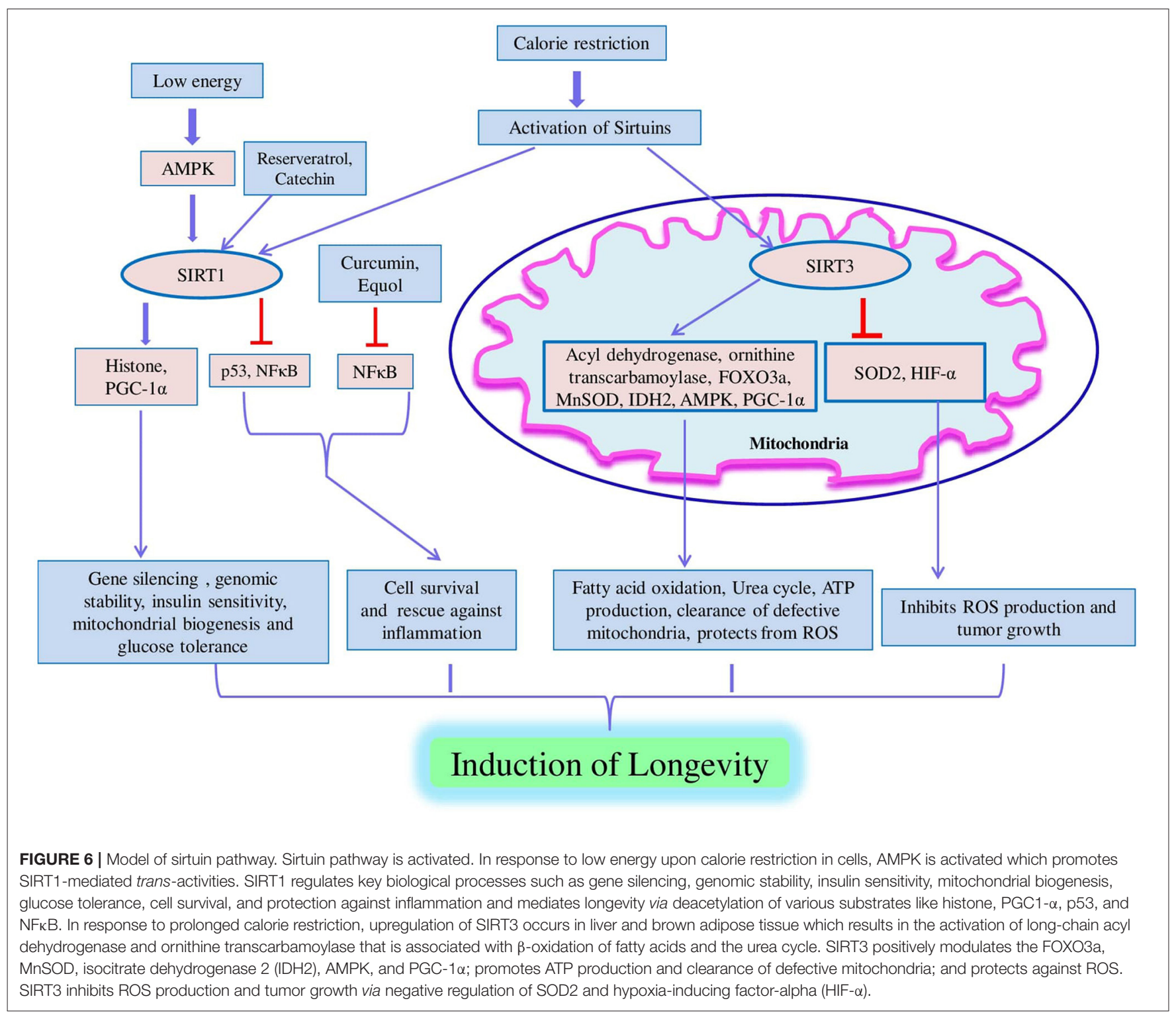

levels of enzymatic and non-enzymatic antioxidants along with lipid peroxides. This was associated with the abundant amounts of phenolics, tannins, and phytates present in finger millets. Furthermore, the effects of methanolic extracts of finger millet and kodo millet on glycation and cross-linking of collagen were studied (Hegde et al., 2002). It is thus proposed that finger millet can have a potential therapeutic role as dietary supplements for the prevention of glycation-induced complications, as in diabetes or aging.

Free radicals are regularly generated in our body as a byproduct of normal aerobic respiration and substrate oxidation. However, the excessive accumulation of these radicals causes damage to vital biomolecules such as carbohydrates, lipids, proteins, and DNA, consequently leading to the manifestation of various age-related diseases. Polyphenols are suggested to exhibit their beneficial antioxidant effects either by scavenging free radicals, chelating metal ions, quenching singlet oxygen, or by inhibiting the reactive oxygen species (ROS) producing enzymes such as myeloperoxidase, lipoxygenase, cyclooxygenase, and xanthine oxidase. Chandrasekara and Shahidi (2011) evaluated the antioxidant properties of phenolic extracts from seven millet varieties [kodo, finger (Ravi), finger (local), proso, foxtail, little, and pearl] on HT-29 cells. All varieties used in this study showed a significant reduction in lipid peroxidation in liposomes, singlet oxygen quenching, and DNA scission inhibition to varying degrees. Furthermore, the cytoprotective effects of various types of millet phenolics (catechin, ferulic acid, vanillic acid, and resveratrol) were investigated, and it was observed that they exhibit preventive effects on protein and human erythrocyte peroxidation (Palaniswamy and Govindaswamy, 2017).

Different studies have also given exclusive attention to finger millet for its pharmacological significance. For instance, the study 


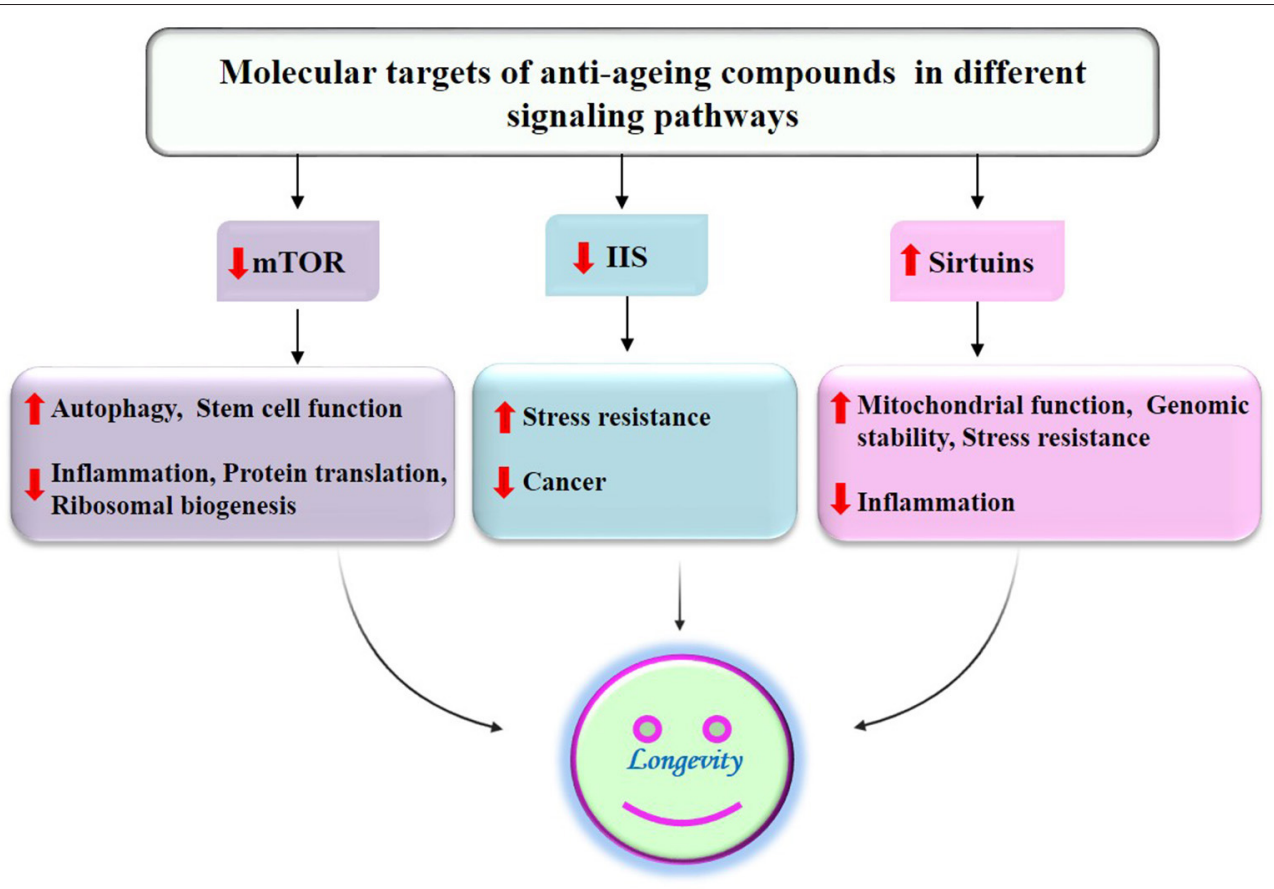

FIGURE 7 | Suppression of aging and age-associated diseases by antiaging compounds of millets through modulation of different signaling pathways by acting on their molecular targets.

conducted on early diabetic rats indicated that the administration of finger millet exhibited its beneficial effects on antioxidant status of the skin, production of nerve growth factor, and woundhealing parameters (Rajasekaran et al., 2004). Ajiboye (2017) also evaluated the antioxidant potential and free radical scavenging ability of whole-grain finger millet. The study revealed that ethanolic extract of whole finger millet effectively scavenged $\mathrm{H}_{2} \mathrm{O}_{2}, \mathrm{NO}$, and DPPH.

Oxidative stress, caused by ROS, is responsible for modulating several pathological conditions during aging. Thus, aging can also be defined as low energy and high oxidative stress state. As studies indicate that the administration of millet may greatly affect the level of reactive oxygen species and hence may also combat age-associated health issues. Though there is a lack of evidence showing the molecular mechanism for antiaging effect of millets, the possible molecular mechanism for antiaging may be explained using different aging theories and preliminary shreds of evidence supporting antiaging effect of millets.

\section{ANTIAGING PROPERTIES AND MOLECULAR INSIGHTS}

Natural compounds offer a repertoire of highly diverse structural scaffolds that can offer hopeful candidate chemical entities with antiaging potential. As per a large number of published pieces of literature, it is highly emphasized that consumption of millet may help in reducing aging and age-related complications. Though, its exact mechanism of action is not known. However, based upon these studies, it can be suggested that phytochemicals obtained from millets can play a significant role in the suppression of aging processes and aging-related diseases by influencing genetic repair, protein glycation, and stress-responsive pathways. The effect of millets on all these pathways can be attributed to their antioxidant property and antiaging potential, as explained below by various aging theories.

\section{Free Radical Theory}

The free radical theory of aging and the antiaging property stated that progressive accumulation of endogenous oxygen radicals causes damage to macromolecular components of the cellrendering cells and organs to stop functioning, ultimately leading to death by senescence (Finkel and Holbrook, 2000). With the discovery of the mitochondrial genome, the theory was modified to the mitochondrial theory of aging in the year 1972. This theory stated that reactive oxygen species (ROS) generated during mitochondrial respiration damages macromolecules including mitochondrial DNA (mtDNA) (Muller et al., 2007). Such mutations in mtDNA which accumulate over time result in increased ROS generation and oxidative damage as suggested by studies conducted in a variety of experimental animal models and tissues (Muller et al., 2007). The grains of millet possess natural antioxidants which help to combat damage induced by free radicals and prolong the lifespan of organisms. This theory has been proven by different experiments as listed in Table 2 .

\section{Telomere Shortening Theory}

Excessive oxidative stress leads to the accumulation of oxidative DNA damage in telomeres and is strongly related to premature aging ( $\mathrm{Lu}$ and Liu, 2010). As per telomere shortening theory, 
aging occurs due to the loss of telomeres. Cellular senescence is initiated by erosion or improper functioning of telomeres resulting in cell-cycle exit after several cell cycles (Holliday, 2014). In each subsequent cellular division, telomere length gets shorter which obstructs the chromosomal ends from being identified as double-strand breaks. DNA damage response gets triggered due to telomere shortening (Karlseder et al., 1999). Apart from telomere shortening, damage in DNA in regions other than telomere is also responsible for aging. Similarly, DNA damage theory also proposes that loss of its functionality during aging process may stem from the accumulation of unrepaired naturally occurring DNA damages like DNA breaks, cross-linking, and base modifications (Hayflick, 2007). With the accumulation of such mutations over time in aged organisms, there is an increased risk of tumor formation and other age-related disorders (Iyama and Wilson, 2013). As per literature, there are several factors inducing DNA damage which in turn are responsible for aging and associated diseases (Figure 2). Naturally occurring compounds in millets act as potent antioxidants which may reduce the level of oxidative stress and hence minimize the rate of telomere shortening.

\section{Protein Translational Modifications}

During aging, the functioning of the proteins can be disturbed due to disorganized protein synthesis and aberrant types of posttranslational modifications (PTMs) such as acetylation, phosphorylation, glycosylation, ubiquitination, sumoylation, and neddylation ultimately leading to the accretion of inactive, denatured, misfolded, and mutated proteins in cells of aged organisms (Santos and Lindner, 2017) (Figure 3). The posttranslational modifications of proteins are chiefly responsible for the activity, stability, as well as protein-protein interactions, influencing the cellular function and metabolism (Santos and Lindner, 2017). It has been observed that different compounds influence the PTMs of different proteins and help in maintaining cellular function during the aging process (Lan et al., 2016; Peleg et al., 2016). In the recent past, a good number of drugs and natural compounds including millets and millet-based products have been studied for their antiaging potential. It was reported that millet extracts inhibited the glycosylation of collagen protein and thus protects its function (Hegde et al., 2002).

\section{NEW PARADIGM FOR DESIGNING ANTIAGING DRUGS DERIVING INFORMATION FROM MILLETS AND OTHER COMPOUNDS OF PLANT ORIGIN}

Various natural products from grains, fruits, and vegetables are studied for their antiaging properties. These natural products or compounds are suggested to delay the aging process by regulating genes involved in different pathways and involved in the aging process. Though the detailed mechanism of action of bioactive compounds of millets has not been explored, preliminary investigations highlight the effect of millet extract on longevity as well as aging-associated diseases. Hence, it is imperative to have detailed investigations of bioactive compounds of millets for their mode of action as antiaging compounds. As per various studies, the premature aging and aging-associated diseases are found to be associated with the fault in the key cellular pathways such as the IIS (Figure 4), mTOR (Figure 5), and sirtuin (Figure 6) molecular networks. Hence, all these crucial pathways involved in the aging process need to be studied focusing on the effect of bioactive compounds of millet extracts on the key molecules of all these pathways in suitable in vitro model systems (Figure 7). Once the molecular mechanism of action of bioactive compounds obtained from millets is revealed, formulations based on these compounds can be processed and targeted to the specific targets in a nanoencapsulated form.

Millets are a rich natural source of antioxidants and thus hold potential as a nutraceutical and functional food ingredient promoting health and reducing the risk of disease. However, more validation in animal models and human subjects needs to be performed to verify their activity and health benefits. The effect of different cellular processes such as methylation, glycosylation, acetylation, phosphorylation, ubiquitination, etc. on aging has been studied by many scientists to find the mechanism by which these processes affect the extent of aging and associated diseases. Several efforts have been made to design some potential drugs that can bind with the target enzyme of cellular processes associated with aging. Some therapeutics such as nutulin-3, HDAC, and MLN4924 have shown their effectiveness in tackling the aging and associated diseases, but no success story of any drug is available in the market that can be recommended for use to prevent aging and its symptoms. The role of some pathways such as the IGF-1 signaling pathway, mTOR signaling pathway, and sirtuin-related pathways is also associated with the aging process. Modulation of these pathways by the use of some potential therapeutics can also be one of the possible approaches to curb the aging process. A comprehensive network of different processes and pathways associated with aging can be designed to find some potential targets for the treatment of aging and associated diseases. Furthermore, validation studies related to these targets can be carried out by in vitro and in vivo studies, if not validated earlier. Structure-based drug designing approach can be applied to design and screen some potential candidate drugs that can modulate the agingassociated pathways by specific binding with the drug target. The druggability of these candidate drugs can be predicted using absorption, distribution, metabolism, and toxicity (ADMT) prediction tools to avoid the chance of drug failure in clinical trials.

Many synthetic and natural compounds such as indolepropionaamide (IPAM), acetyl L-carnitine (ALC), spermidine, metformin, lithocholic acid, caffeine, reserveratrol, rapamycin, epicatechin, and quercetin have shown their potential role in the suppression of the aging process by modulating different drug targets. Mechanisms of action for these compounds are also different for different targets by which they generate the antiaging response. It is important to mention that most of such studies related to aging have been performed in Caenorhabditis elegans, Drosophila 
melanogaster, mice, rat, and worms. The effect of these antiaging compounds needs to be studied in humans to explore the mechanism of action and interaction of compounds with the drug target. Natural ingredients in millets have also shown their antiaging response, but their target and mechanism of action are not explored well scientifically. More studies on the antiaging response of millets are required to validate the target and mechanism of action. Compounds with known antiaging effects can be used as a lead molecule to design more specific and potential candidate drugs for a given drug target. Optimization of lead compounds is very necessary to achieve better bioavailability, specificity, and affinity for the drug target. Computational tools can be more helpful in deciphering the chemical modification required to optimize the activity of a lead molecule. Potential candidate drugs resulted from lead optimization can be recommended for in vitro or clinical testing.

\section{CONCLUSION}

A balanced diet with definite nutritional supplements plays a key role in promoting the lifespan and health of human beings. Various natural compounds from different plants have been found to curb aging and associated diseases. Millets are a chief source of proteins, carbohydrates, and minerals and are low in fat content which validates their utilization in many healthy diets. Furthermore, millets contain high content of total phenolics, flavonoids, and other phytochemicals that have been reported to possess antiaging potential. Henceforth, millets might be utilized in the formulation of nutraceutical and functional foods that can be consumed daily due to the presence of many bioactive compounds that prevent aging and associated diseases. The prospects include the identification, isolation, and characterization of bioactive molecules present in millets that can slow down the aging process. Once characterized, further validation of their mechanism of action at the molecular level can be explored by the wet lab and in silico analysis. The effectiveness

\section{REFERENCES}

Adekunle, A. A. (2012). Agricultural Innovation in Sub-saharan Africa: Experiences From Multiple Stake Holder Approaches. Ghana: Forum for Agricultural Research in Africa (FARA).

Ajiboye, A. A. (2017). Investigation on antioxidants, free radical scavenger and lipid peroxidation activities of whole grains finger millet (Eleusine coracana L.). Int. J. Plant Biol. 8:6684. doi: 10.4081/pb.2017.6684

Altintas, O., Park, S., and Lee, S. J. (2016). The role of insulin/IGF-1 signaling in the longevity of model invertebrates, C. elegans and D. melanogaster. BMB Rep. 49, 81-92. doi: 10.5483/bmbrep.2016.49.2.261

Amadou, I., Amza, T., Shi, Y. H., and Le, G. W. (2011). Chemical analysis and antioxidant properties of foxtail millet bran extracts. Songklanakarin J. Sci. Technol. 33, 509-515.

Badhani, B., Sharma, N., and Kakkar, R. (2015). Gallic acid: a versatile antioxidant with promising therapeutic and industrial applications. RSC $A d v$. 5, 27540-27557. doi: 10.1039/c5ra01911g

Banerjee, S., Sanjay, K. R., Chethan, S., and Malleshi, N. G. (2012). Finger millet (Eleusine coracana) polyphenols: investigation of their antioxidant capacity and antimicrobial activity. Afr. J. Food Sci. 6, 362-374. doi: 10.5897/AJFS12.031 of these bioactive compounds requires evaluation in a cell or tissue-specific manner followed by the animal model system for safety concerns and to determine their therapeutic potency.

\section{AUTHOR CONTRIBUTIONS}

AK gave the manuscript concept. MR and PS wrote the manuscript. SM, DS, HK, and RKV contributed critically in revising the draft and updating the manuscript for publication. All authors contributed to the article and approved the submitted version.

\section{FUNDING}

This research work was conducted under the research program (Grant No. BT/PR7849/AGR/02/2006) funded by the Department of Biotechnology (DBT), New Delhi at G.B. Pant University of Agriculture and Technology, Pantnagar, India. RKV is thankful to the Bill \& Melinda Gates Foundation, USA (Grant ID\# OPP1052922) for supporting millets research at ICRISAT. The logistic support provided by the Director, Experiment Station, G. B. P. U. A. \& T., Pantnagar is also acknowledged.

\section{ACKNOWLEDGMENTS}

The authors acknowledge Ms Geeta Swargiary for her help in formatting and finalizing the references of the manuscript.

\section{SUPPLEMENTARY MATERIAL}

The Supplementary Material for this article can be found online at: https://www.frontiersin.org/articles/10.3389/fsufs. 2021.684318/full\#supplementary-material

Supplementary Figure $\mathbf{S 1}$ | Structure of major phenolic compounds present in millets.

Supplementary Figure S2 | Basic structure of flavonoids reported in millets.

Beal, T., Massiot, E., Arsenault, J. E., Smith, M. R., and Hijmans, R. J. (2017) Global trends in dietary micronutrient supplies and estimated prevalence of inadequate intakes. PLoS ONE 12:e0175554. doi: 10.1371/journal.pone.0175554 Bhat, B. V., Rao, B. D., and Tonapi, V. A., (2018). The Story of Millets. ICAR-IIMR. Bindu, A. C., and Malleshi, N. G. (2003). "Finger millet seed coat polyphenolsconcentration and assay of the antioxidant properties," in Proceeding of the Souvenir, 5th International Food Convention, (SFC'03), AFST(I) (Mysore), 24.

Castelluccio, C., Paganga, G., Melikian, N., Pridham, J., Sampson, J., and Rice-Evans, C. (1995). Antioxidant potential of intermediates in phenylpropanoid metabolism in higher plants. FEBS Lett. 368, 188-192. doi: 10.1016/0014-5793(95)00639-Q

Chandel, G., Kumar, M., Dubey, M., and Kumar, M. (2017). Nutritional properties of minor millets: neglected cereals with potentials to combat malnutrition. Curr. Sci. 107, 1109-1111.

Chandrasekara, A., and Shahidi, F. (2010). Content of insoluble bound phenolics in millets and their contribution to antioxidant capacity. J. Agric. Food Chem. 58, 6706-6714. doi: 10.1021/jf100868b

Chandrasekara, A., and Shahidi, F. (2011). Inhibitory activities of soluble and bound millet seed phenolics on free radicals and reactive oxygen species. $J$. Agric. Food Chem. 59, 428-436. doi: 10.1021/jf103896z 
Chen, C. (2016). Sinapic acid and its derivatives as medicine in oxidative stress-induced diseases and ageing. Oxid. Med. Cell Longev. 2016:3571614. doi: $10.1155 / 2016 / 3571614$

Chen, C., Zhou, M., Ge, Y., and Wang, X. (2020). SIRT1 and aging related signaling pathways. Mech. Ageing Dev. 187, 111-215. doi: 10.1016/j.mad.2020.111215

Chethan, S., Dharmesh, S. M., and Malleshi, N. G. (2008). Inhibition of aldose reductase from cataracted eye lenses by finger millet (Eleusine coracana) polyphenols. Bioorg. Med. Chem. 16, 10085-10090. doi: 10.1016/j.bmc.2008.10.003

Chethan, S., and Malleshi, N. G. (2007). Finger millet polyphenols optimization of extraction and the effect of pH on their stability. Food Chem. 105, 862-870. doi: 10.3923/ajft.2007.582.592

Chondrogianni, N., Kapeta, S., Chinou, I., Vassilatou, K., Papassideri, I., and Gonos, E. S. (2010). Anti-ageing and rejuvenating effects of quercetin. Exp. Gerontol. 45, 763-771. doi: 10.1016/j.exger.2010.07.001

Dhananjaya, B. L., Nataraju, A., Gowda, C. D. R., Sharath, B. K., and Dsouza, C. J. M. (2009). Vanillic acid as a novel specific inhibitor of snake venom 5'-nucleotidase: a pharmacological tool in evaluating their role of the enzyme in snake envenomation. Biochemistry 74, 1315-1319. doi: $10.1134 /$ S0006297909120037

Dykes, L., and Rooney, L. W. (2006). Sorghum and millets phenols and antioxidants. J. Cereal Sci. 44, 236-251. doi: 10.1016/j.jcs.2006.06.007

Everitt, A. V., Hilmer, S. N., Brand-Miller, J. C., Jamieson, H. A., Truswell, A. S., Sharma, A. P., et al. (2006). Dietary approaches that delay age-related diseases. Clin. Interv. Ageing 1, 11-31. doi: 10.2147/ciia.2006.1.1.11

FAO (Food and Agricultural Organization) (2012). Economic and Social Department: The Statistical Division. Statistics Division 2012.

Ferguson, L. R. (2001). Role of plant polyphenols in genomic stability. Mutat. Res. 475, 89-111. doi: 10.1016/S0027-5107(01)00073-2

Finkel, T., and Holbrook, N. J. (2000). Oxidants, oxidative stress and the biology of ageing. Nature 408, 239-247. doi: 10.1038/35041687

Fu, M. X., Knecht, K. J., Thorpe, S. R., and Baynes, J. W. (1992). Role of oxygen in cross-linking and chemical modification of collagen by glucose. Diabetes 41, 42-47. doi: 10.2337/diab.41.2.s42

Harman (1972). A biologic clock: the mitochondria?. J. Am. Geriatr. Soc. 20, 145-147. doi: 10.1111/j.1532-5415.1972.tb00787.x

Hassan, Z. M., Sebola, N. A., and Mabelebele, M. (2021). The nutritional use of millet grain for food and feed: a review. Agric. Food Secur. 10:16. doi: $10.1186 /$ s40066-020-00282-6

Hayflick, L. (2007). Biological ageing is no longer an unsolved problem. Ann. N. Y. Acad. Sci 1100, 1-13. doi: 10.1196/annals.1395.001

Hegde, P. S., Chandrakasan, G., and Chandra, T. S. (2002). Inhibition of collagen glycation and crosslinking in vitro by methanolic extracts of finger millet (Eleusine coracana) and Kodo millet (Paspalum scrobiculatum). J. Nutr. Biochem. 13, 517-521. doi: 10.1016/S0955-2863(02)00 171-7

Hegde, P. S., Rajasekaran, N. S., Chandra, and T. S. (2005). Effects of the antioxidant properties of millet species on oxidative stress and glycemic status in alloxan-induced rats. Nutr. Res. 25, 1109-1120. doi: 10.1016/j.nutres.2005.09.020

Holliday, R. (2014). The commitment of human cells to senescence. Interdiscip. Top. Gerontol. 39, 1-7. doi: 10.1159/000358896

Hong, Y. H., Jung, E. Y., Shin, K. S., Yu, K. W., Chang, U. J., and Suh, H. J. (2013). Tannase-converted green tea catechins and their anti-wrinkle activity in humans. J Cosmet. Dermatol. 12, 137-143. doi: 10.1111/jocd.12038

ICRISAT (2007). ICRISAT Annual Report 2007 'New Horizons of Scientific Excellence for the Semi-Arid Tropics'. Documentation.International Crops Research Institute for the Semi-Arid Tropics, Patancheru.

Itoh, A., Isoda, K., Kondoh, M., Kawase, M., Kobayashi, M., Tamesada, M., et al. (2009). Hepatoprotective effect of syringic acid and vanillic acid on concanavalin A-induced liver injury. Biol. Pharm. Bull. 32, 1215-1219. doi: $10.1248 / \mathrm{bpb} .32 .1215$

Iyama, T., and Wilson, D. M. III. (2013). DNA repair mechanisms in dividing and non-dividing cells. DNA Repair 12, 620-636. doi: 10.1016/j.dnarep.2013.04.015

Jiang, R. W., Lau, K. M., Hon, P. M., Mak, T. C. W., Woo, K. S., and Fung, K. P. (2005). Chemistry and biological activities of caffeic acid derivatives from Salvia miltiorrhiza. Curr. Med. Chem. 12, 237-246. doi: 10.2174/0929867053 363397
Kakkar, S., and Bais, S. (2014). A review on protocatechuic acid and its pharmacological potential. ISRN Pharmacol. 2014:952943. doi: $10.1155 / 2014 / 952943$

Karlseder, J., Broccoli, D., Dai, Y., Hardy, S., and De Lange, T. (1999). P53 and ATM-dependent apoptosis induced by telomeres lacking TRF2. Science 283, 1321-1325. doi: 10.1126/science.283.5406.1321

Khan, A. K., Rashid, R., Fatima, N., Mahmood, S., Mir, S., Khan, S., et al. (2015). Pharmacological activities of protocatechuic acid. Acta Pol. Pharm. 72, 643-650. doi: 10.3390/ijms19061573

Kulkarni, D. B., Sakhale, B. K., and Giri, N. A. (2018). A potential review on millet grain processing. Int. J. Nutr. Sci. 3:1018.

Kumar, A., Metwal, M., Kaur, S., Gupta, A. K., Puranik, S., Singh, S., et al. (2016). Nutraceutical value of finger millet [Eleusinecoracana (L.) Gaertn.], and their improvement using omics approaches. Front. Plant Sci. 7:934. doi: $10.3389 /$ fpls.2016.00934

Kumar, A., Tomer, V., Kaur, A., Kumar, V., and Gupta, K. (2018). Millets: a solution to agrarian and nutritional challenges. Agric. Food Secur. 7:31. doi: 10.1186/s40066-018-0183-3

Kumari, P. L., and Sumathi, S. (2002). Effect of consumption of finger millet on hyperglycemia in non-insulin dependent diabetes mellitus (NIDDM) subjects. Plant Foods Hum. Nutr. 57, 205-213. doi: 10.1023/A:10218050 28738

Kumssa, D. B., Joy, E. J., Ander, E. L., Watts, M. J., Young, S. D., Walker, S., et al. (2015). Dietary calcium and zinc deficiency risks are decreasing but remain prevalent. Sci. Rep. 5:10974. doi: 10.1038/srep10974

Lan, H., Tang, Z., Jin, H., and Sun, Y. (2016). Neddylation inhibitor MLN4924 suppresses growth and migration of human gastric cancer cells. Sci. Rep. 6:24218. doi: 10.1038/srep24218

Lin, Y., Shi, R., Wang, X., and Shen, H. M. (2008). Luteolin, a flavonoid with potentials for cancer prevention and therapy. Curr. Cancer Drug Targets 8, 634-646. doi: 10.2174/156800908786241050

Liu, J., Tang, X., Zhang, Y., and Zhao, W. (2012). Determination of the volatile composition in brown millet, milled millet and millet bran by gas chromatography/ mass spectrometry. Molecules17, 2271-2282. doi: 10.3390/molecules 17032271

Lobo, V., Patil, A., Phatak, A., and Chandra, N. (2010). Free radicals, antioxidants and functional foods: impact on human health. Pharmacogn. Rev. 4, 118-126. doi: 10.4103/0973-7847.70902

Lu, J., and Liu, Y. (2010). Deletion of Ogg1 DNA glycosylase results in telomere base damage and length alteration in yeast. EMBO J. 29, 398-409. doi: 10.1038/emboj.2009.355

Mal, B., Padulosi, S., and Ravi, S. B. (2010). Minor Millets in South Asia: Learnings from IFAD-NUS Project in India and Nepal. Maccarese, Rome, Italy: Bioversity Intl and Chennai, India. New Delhi: M.S. Swaminathan Research Foundation, 1-185.

Manuja, R., Sachdeva, S., Jain, A., and Chaudhary, J. (2013). A comprehensive review on biological activities of p-hydroxy benzoic acid and its derivatives. Int. J. Pharm. Sci. Rev. Res. 22, 109-115.

Mariac, C., Luong, V., Kapran, I., Mamadou, A., Sagnard, F., Deu, M., et al. (2007). Diversity of wild and cultivated pearl millet accessions (Pennisetumglaucum [L.] R. Br.) in Niger assessed by microsatellite markers. Theor. Appl. Genet. 114, 49-58. doi: 10.1007/s00122-006-0409-9

Muller, F. L., Lustgarten, M. S., Jang, Y., Richardson, A., and Van, R. H. (2007). Trends in oxidative ageing theories. Free Radic. Biol. Med. 43, 477-503. doi: 10.1016/j.freeradbiomed.2007.03.034

Murtaza, N., Baboota, R., Jagtap, S., Singh, D., Khare, P., Sarma, S. et al. (2014). Finger millet bran supplementation alleviates obesity-induced oxidative stress, inflammation and gut microbial derangements in highfat diet-fed mice. Br. J. Nutr. 112, 1447-1458. doi: 10.1017/S00071145140 02396

Muthukumaran, J., Srinivasan, S., Venkatesan, R. S., Ramachandran, V., and Muruganathan, U. (2013). Syringic acid, a novel natural phenolic acid, normalizes hyperglycemia with special reference to glycoprotein components in experimental diabetic rats. J. Acute Dis. 2, 304-309. doi: 10.1016/S2221-6189(13)60149-3

Nadro, M. S., and Elkanah, G. (2017). Hypoglycaemic effect of fractions and crude methanolic leaf extract of Phyllanthusfraternus in streptozotocin 
- induced diabetic and normal rats. J. Med. Plants Res. 11, 58-65. doi: 10.5897/JMPR2016.6300

Namikii, M. (1990). Antioxidants/antimutagens in food. Crit. Rev. Food Sci. Nutr. 29, 273-300. doi: 10.1080/10408399009527528

Nithiyanantham, S., Kalaiselvi, P., Mahomoodally, M. F., Zengin, G., Abirami, A., and Srinivasan, G. (2019). Nutritional and functional roles of millets-A review. J. Food Biochem. 43:e12859. doi: 10.1111/jfbc.12859

Obilana, A. B., and Manyasa, E. (2002). "Millets" in Pseudo Cereals and Less Common Cereals: Grain Properties and Utilization Potential, eds P. S. Belton and J. R. N. Taylor (New York, NY: Springer-Verlag), 177-217. doi: 10.1007/978-3-662-09544-7

Ofosu, F. K., Elahi, F., Daliri, E. B., Chelliah, R., Ham, H. J., Kim, J. H., et al. (2020). Phenolic profile, antioxidant, and antidiabetic potential exerted by millet grain varieties. Antioxidants 9:254. doi: 10.3390/antiox9030254

Okoyomoh, K., Okere, O. S., Olowoniyi, O. D., and Adejo, G. O. (2013). Antioxidant and antidiabetic properties of Eleucine coracana (1.) geartn. (finger millet) seed coat matter in streptozotocin induced diabetic rats. Int. J. Adv. Herb. Altern. Med. 1, 1-9.

Ou, S., and Kwok, K. C. (2004). Ferulic acid: pharmaceutical functions, preparation and applications in foods. J. Sci. Food Agric. 84, 1261-1269. doi: $10.1002 /$ jsfa. 1873

Palaniswamy, S. K., and Govindaswamy, V. (2017). Inhibition of metal catalyzed $\mathrm{H} 2 \mathrm{O} 2$ and peroxyl-AAPH mediated protein, DNA and human erythrocytes lipid oxidation using millet phenolics. J. Plant Biochem. Biotechnol. 26, 406-414. doi: 10.1007/s13562-017-0401-2

Pandey, K. B., and Rizvi, S. I. (2009). Plant polyphenols as dietary antioxidants in human health and disease. Oxid. Med. Cell Longev. 2, 270-278. doi: $10.4161 /$ oxim.2.5.9498

Panich, U., Onkoksoong, T., Limsaengurai, S., Akarasereenont, P., and Wongkajornsilp, A. (2012). UVA-induced melanogenesis and modulation of glutathione redox system in different melanoma cell lines: the protective effect of gallic acid. J. Photochem. Photobiol. B 108, 16-22. doi: 10.1016/j.jphotobiol.2011.12.004

Parameswaran, K., and Sadasivam, S. (1994). Changes in the carbohydrates and nitrogenous components during germination of proso millet (Panicummiliaceum). Plant Foods Hum Nutr. 45, 97-102. doi: 10.1007/BF01088466

Pei, K., Ou, J., Huang, C., and Ou, S. (2015). Derivatives of ferulic acid: structure, preparation and biological activities. Ann. Res. Rev. Biol. 5, 512-528. doi: 10.9734/ARRB/2015/14104

Pei, K., Ou, J., Huanga, J., and Oua, S. (2016). p-Coumaric acid and its conjugates: dietary sources, pharmacokinetic properties and biological activities. J. Sci. Food Agric. 96, 2952-2962. doi: 10.1002/jsfa.7578

Peleg, S., Feller, C., Ladurner, A. G., and Imhof, A. (2016). The metabolic impact on histone acetylation and transcription in ageing. Trends Biochem. Sci. $41,700-711$.

Pragasam, S. J., Venkatesan, V., and Rasool, M. (2013). Immunomodulatory and anti-inflammatory effect of $p$-coumaric acid, a common dietary polyphenol on experimental inflammation in rats. Inflammation 36, 169-176. doi: 10.1007/s10753-012-9532-8

Puranik, S., Kam, J., Sahu, P. P., Yadav, R., Srivastava, R. K., Ojulong, H., et al. (2017). Harnessing finger millet to combat calcium deficiency in humans: challenges and prospects. Front Plant Sci. 8:1311. doi: 10.3389/fpls.2017. 01311

Rajasekaran, S., Sivagnanam, K., Ravi, K., and Subramanian, S. (2004). Hypoglycemic effect and aloe vera gel on streptozotocin-induced diabetes in experimental rats. J Med. Food 7, 61-66. doi: 10.1089/109662004322 984725

Rao, B. D., Bhaskarachary, K., Christina, G. D. A., Devi, G. S., and Tonapi, V. A. (2017). Nutritional and hHealth Benefits of Millets. Hyderabad: ICAR-Indian Institute of Millets Research (IIMR).

Rao, M. V. S. S. T. S., and Muralikrishna, G. (2002). Evaluation of the antioxidant properties of free and bound phenolic acids from native and malted finger millet (Ragi, Eleusine coracana Indaf-15). J. Agric. Food Chem. 50, 889-892. doi: 10.1021/jf011210d

Renganathan, V. G., Vanniarajan, C., Karthikeyan, A., and Ramalingam, J. (2020). Barnyard millet for food and nutritional security: current status and future research direction. Front. Genet. 11:500. doi: 10.3389/fgene.2020.00500
Ribarič, S. (2012). Diet and aging. Oxid. Med. Cell Longev. 2012:741468. doi: $10.1155 / 2012 / 741468$

Rowan, S., Bejarano, E., and Taylor, A. (2018). Mechanistic targeting of advanced glycation end-products in age-related diseases. Biochim. Biophys. Acta 1864, 3631-3643. doi: 10.1016/j.bbadis.2018.08.036

Santos, A. L., and Lindner, A. B. (2017). Protein Post-translational modifications: roles in ageing and age-related disease. Oxid. Med. Cell Longev. 2017:5716409. doi: $10.1155 / 2017 / 5716409$

Selvi, V. M., Nirmalakumari, A., and Senthil, N. (2015). Genetic diversity for Zinc, Calcium and Iron content of selected little millet genotypes. J. Nutr. Food Sci. 2015, 5-6. doi: 10.4172/2155-9600.1000417

Senevirathne, I. G. N. H., Abeysekera, W. K. S. M., Abeysekera, W. P. K. M., Jayanath, N. Y., Galbada Arachchige, S. P., and Wijewardana, D. C. M. S.I. (2021). Antiamylase, antiglucosidase, and antiglycation properties of millets and sorghum from Sri Lanka. Evid. Based Complement. Alternat. Med. 2021: 5834915. doi: 10.1155/2021/5834915

Serna-Saldivar, S. O., and Espinosa-Ramírez, J. (2018). Grain Structure and Grain Chemical composition. Sorghum and Millets: Chemistry, Technology, and Nutritional Attributes. AACC International, Elsevier and Woodhead Publishing, UK. doi: 10.1016/B978-0-12-811527-5.00005-8

Shah, P., Kumar, A., Kumar, V., and Tripathi, M. K. (2021). Millets, Phytochemicals and Their Health Attributes in Millet and Millet Technology. Singapore: Springer Nature Singapore Pte Ltd. doi: 10.1007/978-981-16-0676-2_9

Shahidi, F., and Chandrasekara, A. (2013). Millet grain phenolics and their role in disease risk reduction and health promotion: a review. J. Funct. Foods 5, 570-581. doi: 10.1016/j.jff.2013.02.004

Shahidi, F., Janitha, P. K., and Wanasundara, P. D. (1992). Phenolic antioxidants. Crit. Rev. Food Sci. Nutr. 32, 67-103. doi: 10.1080/104083992095 27581

Shankaramurthy, K. N., and Somannavar, M. S. (2019). Moisture, carbohydrate, protein, fat, calcium, and zinc content in finger, foxtail, pearl, and proso millets. Indian J. Health Sci. Biomed. Res. 12, 228-232.

Sharma, D., Jamra, G., Singh, U. M., Sood, S., and Kumar, A. (2017). Calcium biofortification: three pronged molecular approaches for dissecting complex trait of calcium nutrition in finger millet (Eleusine coracana) for devising strategies of enrichment of food crops. Front. Plant Sci. 7:2028. doi: $10.3389 /$ fpls.2016.02028

Sharma, S., Sharma, N., Handa, S., and Pathania, S. (2017). Evaluation of health potential of nutritionally enriched Kodo millet (Eleusinecoracana) grown in Himachal Pradesh, India. Food Chem. 214, 162-168. doi: 10.1016/j.foodchem.2016.07.086

Shlisky, J., Bloom, D. E., Beaudreault, A. R., Tucker, K. L., Keller, H. H., Freund-Levi, Y., et al. (2017). Nutritional considerations for healthy aging and reduction in age-related chronic disease. Adv. Nutr. 8, 17-26. doi: 10.3945/an.116.013474

Shobana, S., Harsha, M. R., Platel, K., Srinivasan, K., and Malleshi, N. G. (2010). Amelioration of hyperglycaemia and its associated complications by finger millet (Eleusine coracana L.) seed coat matter in streptozotocin-induced diabetic rats. Br. J. Nutr. 104, 1787-1795. doi: 10.1017/S0007114510002977

Shobana, S., Kumari, S. R., Malleshi, N. G., and Ali, S. Z. (2007). Glycemic response of rice, wheat and fingermillet based diabetic food formulations in normoglycemic subjects. Int. J. Food Sci. Nutr. 58, 363-372. doi: $10.1080 / 09637480701252229$

Shobana, S., Sreerama, Y. N., and Malleshi, N. G. (2009). Composition and enzyme inhibitory properties of fingermillet (Eleusine coracana L.) seed coat phenolics: mode of inhibition of $\alpha$-glucosidase and pancreatic amylase. Food Chem. 115, 1268-1273. doi: 10.1016/j.foodchem.2009. 01.042

Si, H., and Liu, D. (2014). Dietary antiageing phytochemicals and mechanisms associated with prolonged survival. J. Nutr. Biochem. 25, 581-591. doi: 10.1016/j.jnutbio.2014.02.001

Singh, K. P., Mishra, A., and Mishra, H. N. (2012). Fuzzy analysis of sensory attributes of bread prepared from millet-based composite flours. LWT Food Sci. Technol. 48, 276-282. doi: 10.1016/j.lwt.2012.03.026

Sreeramulu, D., Reddy, C. V. K., and Raghunath, M. (2009). Antioxidant activity of commonly consumed cereals, millets, pulses and legumes in India. Indian J. Biochem. Biophys. 46, 112-115.

Sripriya, G., Antony, U., and Chandra, T. S. (1997). Changes in carbohydrate, free amino acids, organic acids, phytate and $\mathrm{HCl}$ extractability of 
minerals during germination and fermentation of finger millet (Eleusine coracana). Food Chem. 58, 345-350. doi: 10.1016/S0308-8146(96) 00 $187-2$

Sripriya, G., Chandrasekharan, K., Murty, V. S., and Chandra, T. S. (1996). ESR spectroscopic studies on free radical quenching action of finger millet (Eleusine coracana). Food Chem. 57, 537-540. doi: 10.1016/S0308-8146(96)00187-2

Subramanian, S., and Viswanathan, R. (2007). Bulk density and friction coefficients of selected minor millet grains and flours. J. Food Eng. 81, 118-126. doi: 10.1016/j.jfoodeng.2006.09.026

Taofiq, O., González-Paramás, A. M., Barreiro, M. F., and Ferreira, I. C. F. R. (2017). Hydroxycinnamic acids and their derivatives: cosmeceutical significance, challenges and future perspectives, a review. Molecules 22, 281-305. doi: 10.3390/molecules 22020281

Taylor, J. R. N. (2017). "Millets: their unique nutritional and health-promoting attributes," in Gluten-Free Ancient Grains: Cereals, Pseudocereals, and Legumes: Sustainable, Nutritious, and Health-Promoting Foods for the 21st Century. Amsterdam: Elsevier. doi: 10.1016/B978-0-08-100866-9.00004-2

Tovey, F. I. (1994). Diet and duodenal ulcer. J. Gastroenterol. Hepatol. 9, 177-185. doi: 10.1111/j.1440-1746.1994.tb01240.x

Unno, K., Yamamoto, H., Ohtaki, T., Ishikawa, Y., Noda, S., Maeda, K., et al. (2011). Active component in green tea catechins and effective intake period for prevention of age-related brain dysfunction. Anti Ageing Med. 8, 75-81. doi: 10.3793/jaam.8.75

Vinoth, A., and Ravindhran, R. (2017). Biofortification in millets: a sustainable approach for nutritional security. Front. Plant Sci. 8:29. doi: 10.3389 /fpls.2017.00029

Viswanath, V., Urooj, A., and Malleshi, N. G. (2009). Evaluation of antioxidant and antimicrobial properties of finger millet polyphenols (Eleusinecoracana). Food Chem. 114, 340-346. doi: 10.1016/j.foodchem.2008.09.053

Wang, W., Sun, C., Mao, L., Ma, P., Liu, F., Yang, J., et al. (2016). The biological activities, chemical stability, metabolism and delivery systems of quercetin: a review. Trends Food Sci. Technol. 56, 21-38. doi: 10.1016/j.tifs.2016.07.004

Watanabe, M. (1999). Antioxidative phenolic compounds from Japanese barnyard millet (Echinochloautilis) grains. J. Agric. Food Chem. 47, 4500-4505. doi: $10.1021 / \mathrm{jf} 990498 \mathrm{~s}$

Wei, X., Chen, D., Yi, Y., Qi, H., Gao, X., Fang, H., et al. (2012). Syringic acid extracted from herbadendrobii prevents diabetic cataract pathogenesis by inhibiting aldose reductase activity. Evid. Based Complement. Alternat. Med. 2012:426537. doi: 10.1155/2012/426537
Widowati, W., Fauziah, N., Herdiman, H., Afni, M., Afifah, E., Sari, H., et al. (2016). Antioxidant and anti ageing assays of Oryza Sativa extracts, vanillin and coumaric Acid. J. Nat. Remedies. 16, 88-99. doi: 10.18311/jnr/2016/7220

Xiang, J., Apea-Bah, F. B., Ndolo, V. U., Katundu, M. C., and Beta, T. (2019). Profile of phenolic compounds and antioxidant activity of finger millet varieties. Food Chem. 275, 361-368. doi: 10.1016/j.foodchem.2018.09.120

Yang, X., Wan, Z., Perry, L., Lu, H., Wang, Q., Hao, C., et al. (2012). Early millet use in Northern China. Proc. Nat. Acad. Sci. U.S.A. 109, 3726-3730. doi: 10.1073/pnas.1115430109

Yu, M., Zhang, H., Wang, B., Zhang, Y., Zheng, X., Shao, B., et al. (2021). Key signaling pathways in aging and potential interventions for healthy aging. Cells 10:660. doi: 10.3390/cells10030660

Yue, G. G., Gao, S., Lee, J. K., Chan, Y. Y., Wong, E. C., Zheng, T., et al. (2020). A natural flavone tricin from grains can alleviate tumor growth and lung metastasis in colorectal tumor mice. Molecules 25:3730. doi: $10.3390 /$ molecules 25163730

Zhang, X., Shi, G. F., Liu, X. Z., An, L. J., and Guan, S. (2011). Anti-ageing effects of protocatechuic acid from Alpinia on spleen and liver antioxidative system of senescent mice. Cell Biochem. Funct. 29, 342-347. doi: 10.1002/cb f. 1757

Conflict of Interest: The authors declare that the research was conducted in the absence of any commercial or financial relationships that could be construed as a potential conflict of interest.

Publisher's Note: All claims expressed in this article are solely those of the authors and do not necessarily represent those of their affiliated organizations, or those of the publisher, the editors and the reviewers. Any product that may be evaluated in this article, or claim that may be made by its manufacturer, is not guaranteed or endorsed by the publisher.

Copyright (ङ 2021 Kumar, Rani, Mani, Shah, Singh, Kudapa and Varshney. This is an open-access article distributed under the terms of the Creative Commons Attribution License (CC BY). The use, distribution or reproduction in other forums is permitted, provided the original author(s) and the copyright owner(s) are credited and that the original publication in this journal is cited, in accordance with accepted academic practice. No use, distribution or reproduction is permitted which does not comply with these terms. 